\title{
Methanol to Formaldehyde: An Overview of Surface Studies and Performance of an Iron Molybdate Catalyst
}

\author{
Muhammad Irfan Malik, Nicolas Abatzoglou (D) and Inès Esma Achouri * \\ Department of Chemical Engineering and Biotechnology Engineering, Université de Sherbrooke, \\ Sherbrooke, QC J1K 2R1, Canada; muhammad.irfan.malik@usherbrooke.ca (M.I.M.); \\ nicolas.abatzoglou@usherbrooke.ca (N.A.) \\ * Correspondence: Ines.Esma.Achouri@USherbrooke.ca; Tel.: +1-819-821-8000
}

check for updates

Citation: Malik, M.I.; Abatzoglou,

N.; Achouri, I.E. Methanol to

Formaldehyde: An Overview of Surface Studies and Performance of an Iron Molybdate Catalyst. Catalysts 2021, 11, 893. https://doi.org/ $10.3390 /$ catal11080893

Academic Editor: Arnaud Travert

Received: 1 July 2021

Accepted: 21 July 2021

Published: 24 July 2021

Publisher's Note: MDPI stays neutral with regard to jurisdictional claims in published maps and institutional affiliations.

Copyright: (c) 2021 by the authors. Licensee MDPI, Basel, Switzerland. This article is an open access article distributed under the terms and conditions of the Creative Commons Attribution (CC BY) license (https:// creativecommons.org/licenses/by/ $4.0 /)$.
Abstract: Formaldehyde is a primary chemical in the manufacturing of various consumer products. It is synthesized via partial oxidation of methanol using a mixed oxide iron molybdate catalyst $\left(\mathrm{Fe}_{2}\left(\mathrm{MoO}_{4}\right)_{3}-\mathrm{MoO}_{3}\right)$. This is one of the standard energy-efficient processes. The mixed oxide iron molybdate catalyst is an attractive commercial catalyst for converting methanol to formaldehyde. However, a detailed phase analysis of each oxide phase and a complete understanding of the catalyst formulation and deactivation studies is required. It is crucial to correctly formulate each oxide phase and influence the synthesis methods precisely. A better tradeoff between support and catalyst and oxygen revival on the catalyst surface is vital to enhance the catalyst's selectivity, stability, and lifetime. This review presents recent advances on iron molybdate's catalytic behaviour for formaldehyde production-a deep recognition of the catalyst and its critical role in the processes are highlighted. Finally, the conclusion and prospects are presented at the end.

Keywords: iron molybdate; molybdenum oxide; methanol conversion; formaldehyde production; mixed oxides

\section{Introduction}

Methanol is one of the most critical chemical intermediates used in the petrochemical sector. It is a raw material for synthesizing several hydrocarbons and numerous oxidation products [1-4] There is continuous discussion about methanol's successful utilization in methanol's partial oxidation to formaldehyde $[5,6]$. More than $30 \%$ of methanol is used in formaldehyde production every year $[7,8]$.

Formaldehyde is an essential raw material and is widely used in many industrial chemical products such as resins, 1,4-butylene glycol (BDO), poly formaldehyde and pesticides $[9,10]$. In recent years, the annual demand for formaldehyde has exceeded 30 megatons, and formaldehyde production has been remarkably stable [8,11,12]. In 2017, around 52 million formalin tons $\left(37 \%\right.$ by weight aqueous solution of $\mathrm{CH}_{2} \mathrm{O}$ ) were produced, and the annual global consumption of formaldehyde is expected to increase by nearly $5 \%$ over the next few years [13-15]. This increase in the demand for formaldehyde will continue to grow with the manufacturing industry's development, increased demand for disinfectants, cosmetics and pharmaceuticals [16-18].

The commercial generation of formaldehyde first began in 1910 under the silvercatalyzed process and continued for nearly 40 years. In this process, the methanol and air mixture was subjected to $600{ }^{\circ} \mathrm{C}$ under the silver catalyst [14,19-21] and proceeded according to Equation (1).

$$
\mathrm{CH}_{3} \mathrm{OH} \rightarrow \mathrm{CH}_{2} \mathrm{O}+\mathrm{H}_{2} \Delta \mathrm{H}=84 \mathrm{~kJ} / \mathrm{mol}
$$

Silver catalysts have been used in the form of molten metals or dispersed on supports. However, the high temperatures required for the desired selectivity cause the particles to be aggregated and sintered, thus negatively affecting the formaldehyde yield $[6,14,22]$. 
Furthermore, the silver process strictly depends on the reaction conditions, methanol to oxidant ratio, the temperature and the feed's water presence. Therefore, different alternative preparation methods were investigated to increase the selectivity and stability at lower temperature conditions [14,19,22-25].

In 1931, Adkin et al. proposed a new iron-based catalyst (FeMo) to directly oxidize methanol into formaldehyde with an impressive catalytic performance [26,27]. The FeMobased approach for the production of formaldehyde proceeds according to Equation (2) [28].

$$
\mathrm{CH}_{3} \mathrm{OH}+\frac{1}{2} \mathrm{O}_{2} \rightarrow \mathrm{CH}_{2} \mathrm{O}+\mathrm{H}_{2} \mathrm{O} \Delta \mathrm{H}=-159 \mathrm{~kJ} / \mathrm{mol}
$$

Compared to the silver process, the iron-based catalyst needs a low methanol: air mixture at a lower temperature, and it also limits further oxidation [6,22,29-31]. Oxygensaturated methanol vapors were injected into a packed bed reactor, and nearly $90 \%$ yield was obtained, compared to $86 \%$ in the silver-based process [14,32]. The FeMo was found to be more resistant to poisoning; this resulted in an extension of the catalyst's lifespan of 6-12 months [33,34]. Iron molybdate processes have been recorded to operate at a low concentration of methanol, which ultimately makes the process safer and reduces the risk of explosion by fire [35]. The iron molybdate (oxide-based technology) provides a consistent product throughout the catalyst's lifetime and lowers the operating cost [6]. Consequently, in the 1950s, iron molybdate catalysts were used as industrial catalysts to oxidize methanol to formaldehyde [26,34,36-39].

Commercially available iron molybdate catalysts always contain $\mathrm{Fe}_{2}\left(\mathrm{MoO}_{4}\right)_{3}$ and $\mathrm{MoO}_{3}$ [35,40-43]. The catalytic behaviour of the iron molybdate strongly depends on the Mo/Fe ratio [40,44-46]. The activity and selectivity of methanol to formaldehyde has been carried out with the different stoichiometric ratios from 0.02 to 4 . However, a stoichiometric ratio higher than 1.5 has been found the most active and selective composition [44].

Mo segregates from catalytic material at the reactor inlet and the hotspots [47,48]. The volatilized Mo leaves behind an unselective Fe rich species $[49,50]$ and condenses back as a separate layer; this proceeds to form undesired phases and, thus, deactivate the catalyst and reduce the surface area and selectivity $[33,37,39,51,52]$. It encourages the reactor's shutdown, and, consequently, can cause catalyst replacement. The early shutdown of the reactor is due to an increased pressure drop affected by molybdenum oxide precipitation from the gas phase to downstream of the reactor [37,41].

Therefore, considering the economic benefits and a broader positive impact on society, the development of an efficient catalytic system is required to overcome these limitations. Understanding the active sites within the catalytic materials is essential to implement the improvements. After a series of efforts, it was confirmed that the excess molybdenum is needed to compensate the sublimation of $\mathrm{MoO}_{3}$. This provides stable, active and selective catalytic performance $[29,33,53-56]$. Due to the higher density of catalytically active $\mathrm{Fe}_{2}\left(\mathrm{MoO}_{4}\right)_{3}$ as compared to the anisotropic $\mathrm{MoO}_{3}$, many scientists attribute the activity to isotropic $\mathrm{Fe}_{2}\left(\mathrm{MoO}_{4}\right)_{3}$ Still, there is a counter-argument that the $\mathrm{MoO}_{3}$ that is present in the catalytic samples will not only regenerate lost molybdenum and prevent catalytic deactivation due to sublimation of $\mathrm{MoO}_{3}[34,41,57,58]$, but also has a role in keeping a good selectivity for formaldehyde $[55,59]$. Therefore, it is essential to address the role of each oxide phase; for example, whether $\mathrm{Fe}_{2}\left(\mathrm{MoO}_{4}\right)_{3}$ acts as the only support for $\mathrm{MoO}_{3}$, or whether it has intrinsic activity in the process $[47,48,60]$.

Given the excellent performance of ferric molybdate catalysts, it is not easy to find a more selective composition [35,48]. This fact shows that the catalyst's chemical composition is the same as that first reported in 1931. The current study describes previous studies that identified catalytic activity and selectivity for the iron molybdate catalyzed process. In addition, the literature discusses the typical iron molybdate synthesis, its deactivation and whether $\mathrm{Fe}_{2}\left(\mathrm{MoO}_{4}\right)_{3}$ or $\mathrm{MoO}_{3}$ plays a predominantly active role or if there is a common active centre between them. 


\section{Iron Molybdate an Active Catalyst for Methanol to Formaldehyde Production}

Iron molybdate $\mathrm{Fe}_{2}\left(\mathrm{MoO}_{4}\right)_{3}$ has been widely used for various applications such as methanol/propylene oxidation, gaseous methane to liquid fuels such as methanol, and gas sensors and magnetic devices [32,47,50,61-64]. It is a well-established catalyst and is used in the partial oxidation of methanol to formaldehyde. Due to its high selectivity and activity, it can also be used as a catalyst with different supports and formulations for the treatment of alcohols and hydrocarbons and the storage of hydrocarbons and supercapacitors $[63,65,66]$. Iron molybdates are found in nature as ferrous molybdate $\left(\mathrm{FeMoO}_{4}\right)$ and ferric molybdate $\left(\mathrm{Fe}_{2}\left(\mathrm{MoO}_{4}\right)_{3}\right)$. However, only ferric molybdate is active and plays a critical role in methanol's selective oxidation [34]. A Mo/Fe (2-3) stoichiometric ratio is required to achieve industrial molybdate synthesis, which primarily consists of $\mathrm{Fe}_{2}\left(\mathrm{MoO}_{4}\right)_{3}$ and $\mathrm{MoO}_{3}$. To synthesize the ferric molybdate phase, the Mo/Fe ratio must be equal to or greater than 1.5. However, increasing the $\mathrm{Mo} / \mathrm{Fe}$ ratio from 1.5 will cause it to start forming the most desired mixed oxides- $-\mathrm{Fe}_{2}\left(\mathrm{MoO}_{4}\right)_{3} / \mathrm{MoO}_{3}$ crystals [67]. Some physical properties of pure and mixed oxides iron molybdate catalyst are reported in the Table 1.

Table 1. Represents the physical property and selectivity of each oxide in iron molybdate catalyst.

\begin{tabular}{cccc}
\hline & \multicolumn{2}{c}{ Physical Properties $[25,28,34,68,69]$ and Selectivity of Pure Oxide Phases } \\
\hline Phases & Mol. Weight $[\mathbf{g} / \mathbf{m o l}]$ & Color & Selectivity Towards \\
\hline $\mathrm{Fe}_{2} \mathrm{O}_{3}$ & 159.69 & Red-brown & $\mathrm{CO}_{2}[32,70,71]$ \\
\hline $\mathrm{MoO}_{2}$ & 127.94 & Dark blue-violet & Primarily CO and small amounts of $\mathrm{CO}_{2}[32,72]$ \\
\hline $\mathrm{FeMoO}_{4}$ & 215.78 & Light green & $\mathrm{CO}[32,37]$ \\
\hline $\mathrm{MoO}_{3}$ & 143.94 & White-yellow & Formaldehyde $[32,47,73]$ \\
\hline $\mathrm{Fe}_{2}\left(\mathrm{MoO}_{4}\right)_{3}$ & 591.56 & Brown-yellow-green & Primarily formaldehyde $[32,47,74]$ \\
\hline
\end{tabular}

The production of formaldehyde from methanol is not only limited to the iron molybdenum catalysts. As mentioned earlier, silver and many alternative catalysts have also been used as industrial catalysts in formaldehyde production [22,35,42,75-82].

Currently, worldwide formaldehyde production is divided almost equally between the silver catalyzed process and the use of oxide-based catalysts [12,14,22]. The silver-based process uses methanol-rich feed, whereas the oxide-based process (Formox process) has less methanol-rich contents. The oxide-based catalyst has achieved $93 \%$ selectivity compared to the $<90 \%$ of silver-based catalyst. However, the silver process has a somewhat lower investment cost than the oxide-based process, but the selectivity is an essential parameter because the cost of methanol covers $94 \%$ of production cost compared to power and catalyst cost, which are $4 \%$ and $2 \%$, respectively $[22,36,83]$.

Typical performance data of oxidative dehydrogenations, ammoxidation, and selective hydrocarbon oxidations are presented in Table 2. The data shows that $\mathrm{MoO}_{3} / \mathrm{Fe}_{2}\left(\mathrm{MoO}_{4}\right)_{3}$ has shown remarkable performance with $92-95 \%$ selectivity covering a $99 \%$ conversion rate at lower temperatures than the various other catalysts.

The data shows that the other catalyst has lesser selectivity and conversation and requires a high temperature. 
Table 2. Comparison of different oxide catalysts for selective hydrocarbon oxidation and oxidative dehydrogenation.

\begin{tabular}{|c|c|c|c|c|}
\hline Process & Catalyst & Selectivity (\%) & Conversion (\%) & Temperature $\left({ }^{\circ} \mathrm{C}\right)$ \\
\hline Methanol to formaldehyde [84] & Fe-Mo-O & $92-95$ & $>99$ & $250-380$ \\
\hline Propene to acrylonitrile [85] & Bi-Mo-O & $80-83$ & 98 & $420-450$ \\
\hline Propane to acrylonitrile [86] & $\mathrm{VSbWOx} / \mathrm{SiO}_{2}-\mathrm{Al}_{2} \mathrm{O}_{3}$ & 67 & 60 & 500 \\
\hline Propane to acrylic acid [87] & Mo-V-Nb-Te-O & $50-60$ & 80 & $350-400$ \\
\hline Propane to propene [88] & $\mathrm{V}-\mathrm{O} / \mathrm{MCF}$ & 68 & 41 & 550 \\
\hline Xylene to phthalic anhydride [89] & $\mathrm{V}-\mathrm{O} / \mathrm{TiO}_{2}$ & $80-82$ & 99.9 & $350-450$ \\
\hline Ethene to ethylene oxide [90] & $\mathrm{Ag} / \mathrm{Al}_{2} \mathrm{O}_{3}$ & $80-90$ & $7-15$ & $200-300$ \\
\hline Propane to propylene [86] & V-silicalite & 30 & 70 & 550 \\
\hline Propane to acrylonitrile [91] & Mo-V-Nb-Te-O & 72 & 76 & 420 \\
\hline Ethylene/Acetic acidto Vinyl acetate [92] & $\mathrm{Pd}-\mathrm{Cu}-\mathrm{K}$ on $\mathrm{Al}_{2} \mathrm{O}_{3}$ & 92 & $8-12$ & - \\
\hline Ethanol to butanol [93] & $20 \% \mathrm{Ni} / \mathrm{Al}_{2} \mathrm{O}_{3}$ & 25 & 80 & 250 \\
\hline Propane to propylene [86] & $\mathrm{V}-\mathrm{MgO}$ & 38 & 62 & 540 \\
\hline Ethane to ethylene [94] & $\mathrm{Ni}-\mathrm{NbO}$ & 51 & 90 & 400 \\
\hline Ethane to ethylene [86] & $\mathrm{MoVTeNbO}$ & 85 & 88 & 400 \\
\hline Propene to acrolein [95] & Bi-Mo-O & $83-90$ & $<98$ & $300-400$ \\
\hline Butane to maleic anhydride [96] & $\mathrm{V}-\mathrm{P}-\mathrm{O}$ & $65-73$ & $75-85$ & $350-420$ \\
\hline
\end{tabular}

Substantial research has been performed on the catalyst to find alternative compositions $[84,97,98]$. As a result, molybdates and vanadates gained much of the focus as these materials were found most efficient and selective for partial oxidation of methanol. Figures 1 and 2 show the performance of various molybdates and vanadates, and it is concluded that commercial iron molybdates have the most productive performance compared to other materials.

The primary chemical composition of the iron molybdate catalyst has not changed over the years. Despite this fact, fourfold productivity has been achieved due to some process improvements since the early 1960s, as shown in Table $3[99,100]$.

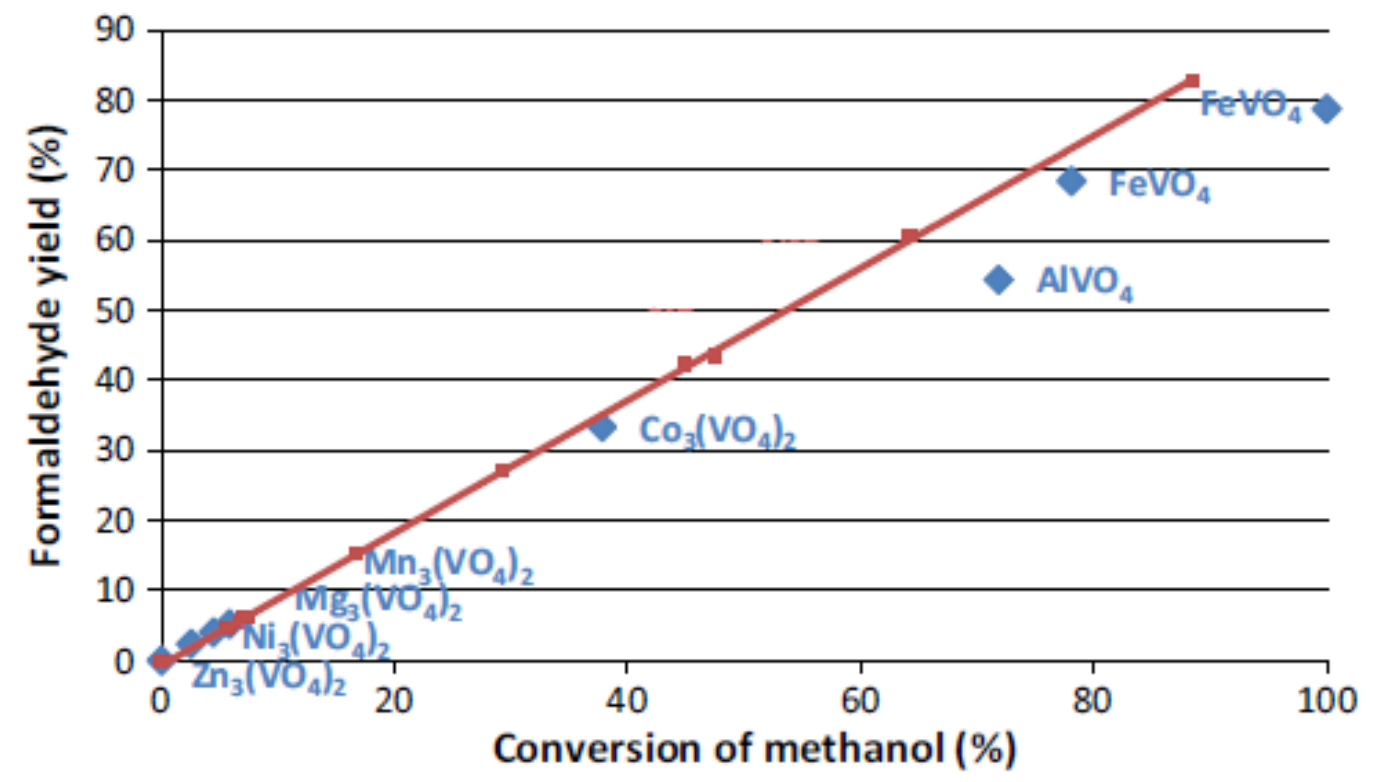

Figure 1. Comparisons of the yield and conversion of formaldehyde over the various vanadates in the Formox (oxide-based catalyst) process. Reprint from [99]. Copyright (2021) from Springer Nature. 


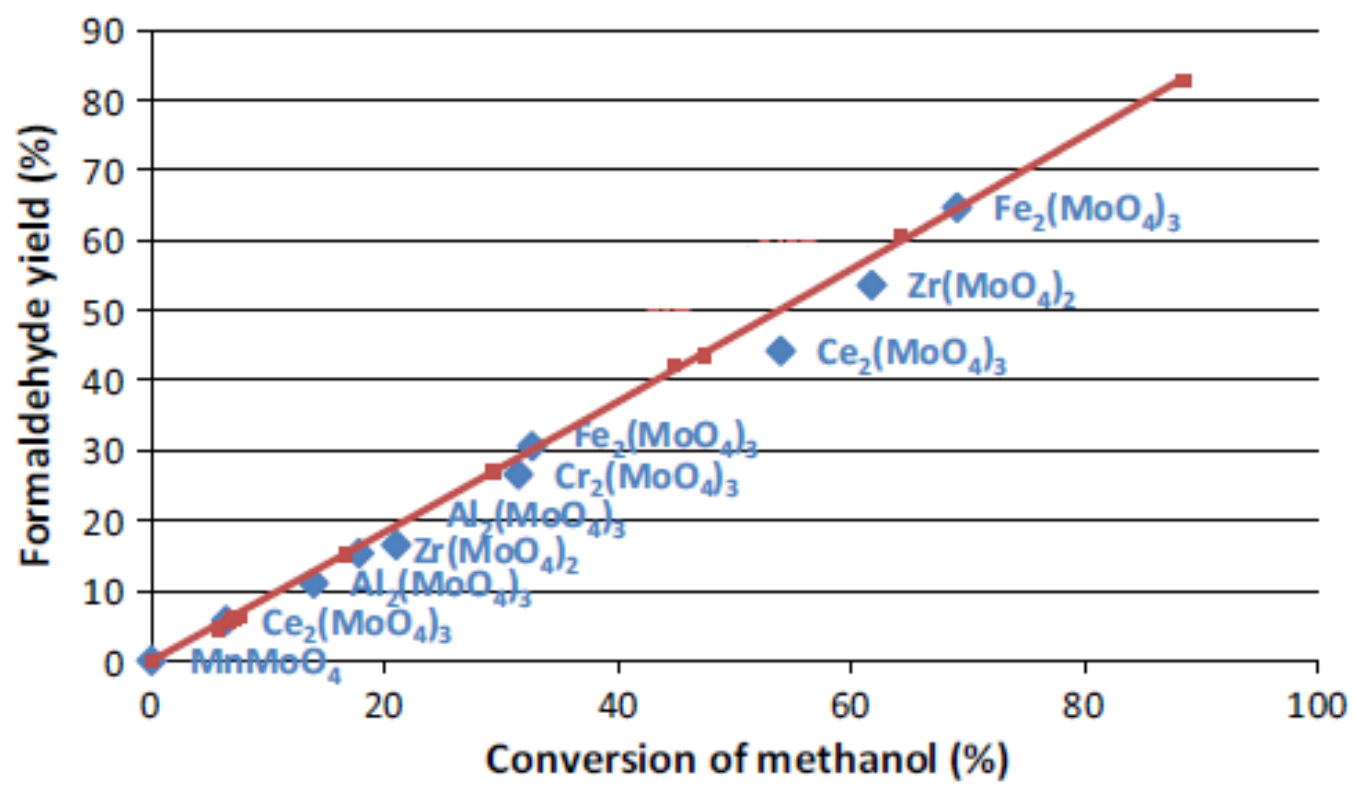

Figure 2. Comparisons of the yield and conversion of formaldehyde over the various molybdates in the Formox process. Reprints from [99]. Copyright (2021), with permission from Springer Nature.

Table 3. Represents the development of the Formox process over the iron molybdate catalyst from the year 1959 [99,100].

\begin{tabular}{|c|c|c|}
\hline Years & Process Development & Results \\
\hline 1959 & $\begin{array}{l}\text { Dried granules of catalyst were used, and the feed } \\
\text { consisted of } 6.5 \mathrm{vol} \% \text { methanol in the air. }\end{array}$ & First Production Scale \\
\hline 1972 & $\begin{array}{l}\text { Gas recirculation, } 7.5 \mathrm{vol} \% \text { methanol, and } \\
10-11 \text { vol } \% \mathrm{O}_{2} \text { pre-calcined granules. }\end{array}$ & $\begin{array}{l}\text { The gas recirculation and lower oxygen concentration } \\
\text { increased productivity and reduced emissions. }\end{array}$ \\
\hline 1984 & Introduced the ring-shaped catalyst. & $\begin{array}{l}\text { Improved gas velocity, lowered the pressure drop and } \\
\text { eventually expanded the productivity. }\end{array}$ \\
\hline 1984 & Introduced the emission control system. & Better environmental impact and steam generation system. \\
\hline 1997 & $\begin{array}{l}\text { New loading system for faster and consistent } \\
\text { loading with increased pressurization ( } 0.3 \text { bar). }\end{array}$ & Enhancement in productivity. \\
\hline 2003 & $\begin{array}{l}\text { New design standards and introduction of catalyst } \\
\text { activity profile (CAP) with higher methanol inlet. }\end{array}$ & Productivity improvements. \\
\hline 2005 & Pressurization to 0.5 bar g. & Productivity improvements. \\
\hline 2009 & Launched CAP 2.0. & Higher yield, lower pressure drop, less aging. \\
\hline 2011 & CAP 2.0, introduction of turbo charger. & $\begin{array}{l}\text { Reduced power consumption, } \\
\text { reduced operational cost. }\end{array}$ \\
\hline 2012 & Launched CAP 3.0. & $\begin{array}{l}\text { Yield and lifetime improvement and enabled the } \\
\text { operation at even higher methanol inlet (up to } 11 \mathrm{vol} \% \text { ). }\end{array}$ \\
\hline 2016 & Complete loading/reloading service concept. & $\begin{array}{l}\text { Reduced the downtime, lowered the risk issues related } \\
\text { to unclean tubes. }\end{array}$ \\
\hline 2018 & $\begin{array}{l}\text { Addition of new high pressure plant design features } \\
2.0 \text { bar with a newly developed catalyst system. }\end{array}$ & Better performance, flexibility and rise in productivity. \\
\hline
\end{tabular}

Due to the various advantages discussed already, $\mathrm{Fe}_{2}\left(\mathrm{MoO}_{4}\right)_{3}$ has established itself as a leading commercial catalyst for formaldehyde production [26]. This is due to its nature to oxidize methanol at fairly low-temperature conditions and retain catalytic activity for repeated use. However, it is essential to identify whether $\mathrm{Fe}_{2}\left(\mathrm{MoO}_{4}\right)_{3}$ supports $\mathrm{MoO}_{3}$ or whether it has an intrinsic activity. It has been believed that $\mathrm{Fe}_{2}\left(\mathrm{MoO}_{4}\right)_{3}$ has outstanding properties, such as the oxygen mobility of the mass lattice. This permits the catalyst to guarantee oxygen revival at the surface at any time throughout the reaction and maintains the catalyst selectivity [47]. 


\section{Synthesis of Iron Molybdate}

The synthesis process of iron molybdate significantly affects the choice of the reactor (fixed or fluidized bed) used in the partial oxidation of methanol. The bulk usage of catalysts and the impact of mechanical abrasion influence the reactors. Therefore, many efforts have been counted to use various synthesis procedures to control and modify the catalyst surface to withstand the mechanical abrasion [34,101,102].

$\mathrm{Fe}_{2}\left(\mathrm{MoO}_{4}\right)_{3}$ is most commonly synthesized by the coprecipitation method in the industry using $\mathrm{FeCl}_{3}$ and ammonium heptamolybdate aqueous solutions [34,103,104]. Later, the precipitate is washed, filtered and calcined at $400-500{ }^{\circ} \mathrm{C}$ to obtain the $\mathrm{Fe}_{2}\left(\mathrm{MoO}_{4}\right)_{3}$ and $\mathrm{MoO}_{3}$ crystals with a surface area of 5-8 $\mathrm{m}^{2} / \mathrm{g}$ [104,105]. Many studies focused on iron molybdate catalyst prepared by coprecipitation methods to influence the catalyst's selectivity and activity. The catalyst prepared by coprecipitation was found to be very selective $[26,28,55,69,106-110]$ and successfully produced formaldehyde from methanol with high yield [14]. However, the high cost of the expensive reagents used in coprecipitation synthesis, the large amount of water required in commercial manufacturing, the evolution of gases as impurities during calcination and the small surface area that hinders the reoxidation rate of the spent catalyst are significant problems associated with coprecipitation synthesis $[107,111,112]$. In addition, slight changes in the synthesis process significantly alter the catalyst properties and adversely affect the surface properties. Therefore, it is essential to find alternative synthesis methods that involve low-cost reagents, reduced water consumption, and a more homogenous consistency with less impact on environmental pollution [24].

Soares et al. [106,113] proposed the sol-gel method as it is considered one of the most suitable low-temperature methods that prepares the iron molybdate without coprecipitation. It was observed that the catalyst prepared with the sol-gel method had a better distribution/dispersion of excess $\mathrm{MoO}_{3}$ over $\mathrm{Fe}_{2}\left(\mathrm{MoO}_{4}\right)_{3}$ as it prevents the Mo volatilization and increases the selectivity of formaldehyde. However, the sol-gel method's catalyst was less active than the coprecipitation method because of the early irreversible surface reduction during the calcination process. It is essential to conduct the calcination below $400{ }^{\circ} \mathrm{C}$ in the sol-gel technique to avoid agglomeration, loss of mechanical strength and surface reduction $[34,106,113]$.

Beale et al. [111] used a single-step hydrothermal approach to prepare the iron molybdate catalysts with a different atomic ratio at reasonably low temperatures compared to other methods. The catalysts produced via hydrothermal processes had mixed $\mathrm{Mo}_{5} \mathrm{O}_{14}$ and FeMo crystalline structures and were unstable at a temperature above $300{ }^{\circ} \mathrm{C}$. The catalyst surface can easily be modified, and its potential synthesis at low temperatures could prepare the material with varying catalytic performance. In the hydrothermal process, the iron and molybdate solution was thermally treated at $150{ }^{\circ} \mathrm{C}$ in an autoclave reactor. Later the crystals were washed, filtered and dried to obtain the iron molybdate with excess molybdenum crystals without calcination.

Recently, Kong et al. [16] prepared the iron molybdate by the mechanochemistry approach using the grinding mill from 30-120 min. It was solvent-free and simplified compared to the traditional coprecipitation method, thus can easily be implemented in industrial-scale applications. The small ball size material and longer grinding time, for example, $120 \mathrm{~min}$, had better crystallinity and selectivity of formaldehyde $(97.56 \%)$ in comparison with larger particles and materials prepared with less milling time. The leading production of formaldehyde was attributed to $\mathrm{Fe}_{2}\left(\mathrm{MoO}_{4}\right)_{3}$ uniformity and to the grinding time.

Nikolenko et al. [50] prepared an iron molybdate catalyst with an ammonium molybdoferrate (II) precursor instead of the conventional Fe(III) precursor used for commercial iron molybdate catalysts. The Fe (II) synthesized iron molybdate has reduced the detrimental impurities (Fe(III) oxide) and protected the catalyst surface; it also reduced the acidity of the prepared solution. The catalyst prepared with Fe (II) showed similar activity to a commercial catalyst in the partial oxidation of methanol to formaldehyde. 
Iron molybdate catalysts can be prepared with the kneading and evaporation method [104]. In this process, ammonium molybdate is dissolved in water, followed by the dropwise addition of iron nitrate powder. Following that, the mixture was subjected to evaporation, and the final product was dried and calcined. Li et al. [114] have examined wet and dry methods to prepare the iron molybdate crystals and observed the $\mathrm{Fe}_{2}\left(\mathrm{MoO}_{4}\right)_{3}$ and $\mathrm{MoO}_{3}$ crystals after the calcination. The wet method recorded the higher performance and had a better and uniform encapsulation of Mo species. However, the bridging of Mo with Fe through oxygen could not be verified in this work.

Popov et al. [115] used molybdic acid and Fe oxalate to prepare the iron molybdate catalyst using centrifugal milling. The milling process reduced the synthesis temperature. However, the article lacks the necessary details to highlight additional advantages.

Hasan et al. prepared the catalyst (iron molybdate) with the mechanical mixing of $\mathrm{MoO}_{3}$ and $\mathrm{Fe}_{2} \mathrm{O}_{3}$; the materials were mixed, ground and then calcined at $600-700{ }^{\circ} \mathrm{C}$ for 10-70 h; however, they had less surface area and were eventually found to be inactive and not selective [104,116].

Iron molybdate also has been prepared using amorphous reagents without coprecipitation. Ferric nitrate, excess citric acid, and ammonium heptamolybdate were used as regents, followed by the calcination at $400{ }^{\circ} \mathrm{C}$ over $6 \mathrm{~h}$. However, no such comparison of this method with conventional coprecipitation has been reported in the literature [117].

Role of $p H$

It is recognized that physical and chemical interaction strongly influence the catalytic behaviour and $\mathrm{Mo} / \mathrm{Fe}$ stoichiometric ratio [33,48-51,118]. For example, the preparation methods, the precursor's initial concentration, and the $\mathrm{pH}$ during precipitation are significant factors [34]. In a typical laboratory coprecipitation method, the precipitation of $\mathrm{Fe}_{2}\left(\mathrm{MoO}_{4}\right)_{3}$ with a Mo/Fe atomic ratio greater than 1.5 is usually carried out between $\mathrm{pH} 1.5$ and 2.0. The $\mathrm{pH}$ of the solution is maintained primarily using $\mathrm{HNO}_{3}$, while the preparation temperature can fluctuate from room temperature to the boiling temperature of the mother solution. Several authors obtained a different $\mathrm{Mo} / \mathrm{Fe}$ atomic ratio by changing the same ratio in the parent solution $[34,119,120]$.

However, Alessandrini et al. [119] reported that the variations in the $\mathrm{Mo} / \mathrm{Fe}$ atomic ratio of the catalyst follow the same degree of variation of the parent solution only when the $\mathrm{pH}$ of the precipitate remains constant. If the $\mathrm{Mo} / \mathrm{Fe}$ contents in the catalyst are less than the Mo/Fe contents in the parent solution, this increases the final $\mathrm{pH}$ of precipitates. Similar unfollowing was also noticed when $\mathrm{HCl}$ was used to maintain the $\mathrm{pH}$ instead of $\mathrm{HNO}_{3}$.

On the contrary, Kolovertnov et al. [120] prepared the iron molybdate catalyst with the coprecipitation method at constant $\mathrm{pH}=2$; the obtained catalyst had a different $\mathrm{Mo} / \mathrm{Fe}$ atomic constitution compared to the parent solution.

Wilson et al. [121] synthesized the iron molybdate catalyst and noticed that the $\mathrm{Mo} / \mathrm{Fe}$ ratio of the catalyst does not depend upon the temperature of precipitation and the addition of order in the mother solution. Moreover, the precipitation steps do not affect the composition. Instead, the washing of precipitates before the drying significantly increased the catalyst's Mo/Fe atomic ratio because Fe has more solubility than molybdenum. However, the article fails to mention that the reported rise in $\mathrm{Mo} / \mathrm{Fe}$ contents due to washing is limited to the bulk or surface of the catalyst.

Energy-intensive annealing and maintaining a $\mathrm{pH}$ of less or equal to 2 are the significant disadvantages reported in the literature. In addition, it was noted that increasing the $\mathrm{pH}$ from 2 caused a significant loss of Mo contents in the mother solution.

Therefore, Nikolenko et al. [50] prepared an iron molybdate catalyst with an ammonium molybdoferrate (II) precursor instead of the conventional Fe(III) precursor used for commercial iron molybdate catalysts. The Fe (II) synthesized iron molybdate was successfully prepared between $\mathrm{pH} 5$ and 6, thus reducing the prepared solution's acidity. In 
addition, the catalyst prepared with Fe (II) showed similar activity to a commercial catalyst in partial oxidation of methanol to formaldehyde.

Although the iron molybdate catalyst has been synthesized for many years, there is still scope to expand and improve the catalytic system and develop an understanding of the synthesis process $[48,66,118]$.

\section{Role of $\mathrm{Fe}_{2}\left(\mathrm{MoO}_{4}\right)_{3}$ as an Active Phase in Partial Oxidation of Methanol}

Classifying the active phase is slightly more complicated as $\mathrm{Fe}_{2}\left(\mathrm{MoO}_{4}\right)_{3}-\mathrm{MoO}_{3} \mathrm{com}-$ pounds containing mixed oxides show excellent formaldehyde selectivity with different activity levels [34]. It has been observed that improved catalytic activity of the iron molybdate catalyst is mainly due to the increase in the number of catalytically active sites of $\mathrm{Fe}_{2}\left(\mathrm{MoO}_{4}\right)_{3}$ [122]. In contrast, the reduced activity of $\mathrm{MoO}_{3}$ is due to the minimal surface of $\mathrm{MoO}_{3}$. Therefore, $\mathrm{Fe}_{2}\left(\mathrm{MoO}_{4}\right)_{3}$ has been identified as the active ingredient, and excess molybdenum is considered a bystander phase $[29,110,119]$.

In 1965 Kolovertnov et al. started studying Mo-Fe-O catalysts with various Mo/Fe atomic compositions in methanol's partial oxidation to formaldehyde [96]. The authors noticed that the $\mathrm{Mo} / \mathrm{Fe}$ atomic ratio of 1.7 is the optimum combination to convert methanol to formaldehyde [123]. After that, Boreskov et al. validated the findings of Kolovertnov and derived the maximum activity at $\mathrm{Mo} / \mathrm{Fe}=1.7$, as well as nominating $\mathrm{Fe}_{2}\left(\mathrm{MoO}_{4}\right)_{3}$ as an active phase and observing that Mo excess is mandatory to regenerate the active sites [123]. Soares et al. [113] carried out partial methanol oxidation under the two different atomic compositions (Mo:Fe 1.5:1) and (Mo:Fe 3:1). The temperature programmed desorption (TPD) confirmed that the $\mathrm{Fe}_{2}\left(\mathrm{MoO}_{4}\right)_{3}$ is 2-4 times more active than bulk $\mathrm{MoO}_{3}$ at the stoichiometric stage. Their studies confirmed that $\mathrm{Fe}_{2}\left(\mathrm{MoO}_{4}\right)_{3}$ is the active phase because increasing Mo's amount can increase selectivity, but the fundamental activity per unit surface is unchanged [124].

Okamoto et al. [57] dispersed Mo over the $\mathrm{Fe}_{2}\left(\mathrm{MoO}_{4}\right)_{3}$ and confirmed that $\mathrm{Fe}_{2}\left(\mathrm{MoO}_{4}\right)_{3}$ was an active phase with a Mo/Fe ratio of 1.7. However, Sun-Kou et al. [58] hold $\mathrm{Fe}_{2}\left(\mathrm{MoO}_{4}\right)_{3}$ as an active phase under the $\mathrm{Mo} / \mathrm{Fe}(>1.7)$ and concluded the $\mathrm{Fe}_{2}\left(\mathrm{MoO}_{4}\right)_{3}$ is responsible for an increase in the electronic properties of the catalytic surface. Table 4 represents the consequence of the Mo/Fe ratio on the conversion and selectivity of formaldehyde.

Table 4. Activity, selectivity, and specific surface area of the iron molybdate catalyst under various $\mathrm{Mo} / \mathrm{Fe}$ ratios [69].

\begin{tabular}{cccc}
\hline $\begin{array}{c}\mathbf{M o} / \mathbf{F e} \\
\text { Ratio in the Catalyst }\end{array}$ & Conversion at $\mathbf{1 8 0}{ }^{\circ} \mathbf{C}$ & Selectivity & Surface Area $\left(\mathbf{m}^{\mathbf{2}} \mathbf{g}\right)$ \\
\hline $0\left(\mathrm{Fe}_{2} \mathrm{O}_{3}\right)$ & 2 & $0\left(322^{\circ} \mathrm{C}\right)$ & 2.1 \\
0.2 & 55 & $18\left(204^{\circ} \mathrm{C}\right)$ & 55.4 \\
0.5 & 50 & $27\left(210^{\circ} \mathrm{C}\right)$ & 38.7 \\
1 & 38 & $47\left(244^{\circ} \mathrm{C}\right)$ & 16.3 \\
1.5 & 35 & $73\left(249^{\circ} \mathrm{C}\right)$ & 7.8 \\
2.2 & 29 & $90\left(256^{\circ} \mathrm{C}\right)$ & 6.7 \\
\hline
\end{tabular}

Alessandrini et al. [119] introduced Mo (VI) to the crystal network of iron molybdate (mixed oxides) and recognized $\mathrm{MoO}_{3}$ as an essential factor in improving catalyst homogeneity and texture. The stoichiometric phase (Fe) is the active phase, indicating that an excess of Mo does not affect Mo-Fe-O's specific activity. However, excess Mo was needed to obtain a catalyst with a large surface area and prevent iron-rich phases during the reaction [34].

Weckhuysen and Wachs state that MO bonds are so stable under reaction conditions that they cannot directly be involved in the selective oxidation reaction [125]. Van Truong et al. [126] found an increase in the catalyst's surface area and mechanical strength while introducing excess Mo in the crystal structure. Söderhjelm et al. [69] reported a mixture of crystal phase $\mathrm{MoO}_{3}$ and $\mathrm{Fe}_{2}\left(\mathrm{MoO}_{4}\right)_{3}$, a top-performing catalyst, and confirmed 
that $\mathrm{MoO}_{3}$ is more selective than pure $\mathrm{Fe}_{2}\left(\mathrm{MoO}_{4}\right)_{3}$ but less active than $\mathrm{Fe}_{2}\left(\mathrm{MoO}_{4}\right)_{3}$. Wachs and Routray [127] and Routray et al. [29]. experienced similar activity for both $\mathrm{Fe}_{2}\left(\mathrm{MoO}_{4}\right)_{3}$ and $\mathrm{MoO}_{3}$ using the methanol-TPSR (temperature-programmed surface reaction).

Recently, Gaur et al. [41] studied the structural changes in iron molybdate $(\mathrm{Mo} / \mathrm{Fe}=2.0)$ during the partial oxidation of methanol to formaldehyde. It was observed that exposing the catalyst to the feed during the initial time on stream, the $\alpha-\mathrm{MoO}_{3}$ volatilized while $\mathrm{Fe}_{2}\left(\mathrm{MoO}_{4}\right)_{3}$ remained stable. It was further seen that $\alpha-\mathrm{MoO}_{3}$ volatilization was enhanced with the rise in methanol formation, and it increased the temperature and reduced the oxygen contents. The extensive characterization in the studies confirmed the vital role of catalyst selectivity and stability.

It is concluded from the literature discussed that $\mathrm{Fe}_{2}\left(\mathrm{MoO}_{4}\right)_{3}$ is an active phase. However, the correct formulation of $\mathrm{Mo} / \mathrm{Fe}$ is vital to balance the presence of Mo and Fe. The presence of Mo is essential to prevent the formation of undesired products and increase selectivity.

\section{Role of Excess $\mathrm{MoO}_{3}$ in Iron Molybdate Catalyst}

From 1980, the industrial application of $\mathrm{MoO}_{3}$ encouraged significant research on hydrodesulfurization, hydrocracking and the selective oxidation of alcohols [104,128,129]. Specifically, $\mathrm{MoO}_{3}$ served as an ideal addition for the partial oxidation of methanol to formaldehyde.

$\mathrm{MoO}_{3}$ is a highly valued material due to its capacity to improve formaldehyde selectivity when used with an iron molybdate catalyst [59].The typical structural unit cell of $\mathrm{MoO}_{3}$ is represented in Figure 3 [130].

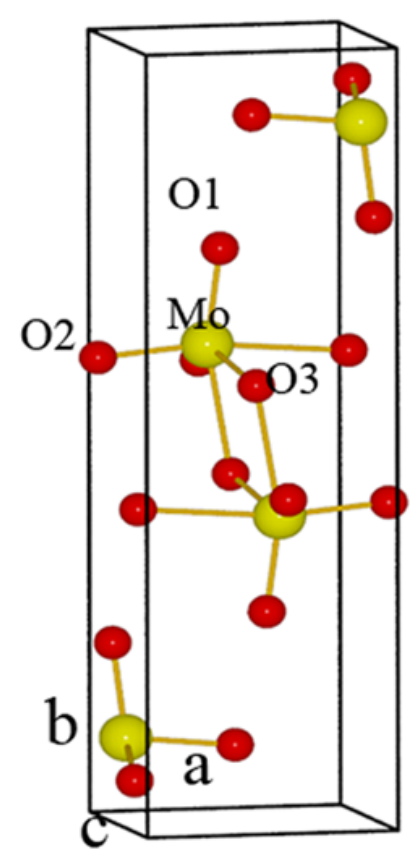

Figure 3. The crystal structure of $\mathrm{MoO}_{3}$ unit cell. Reprint from [130]. Copyright (2021), with permission from Springer Nature.

Söderhjelm et al. proposed that each mixed oxide has a unique role in the partial oxidation of methanol [69]. For example, $\mathrm{MoO}_{3}$ divides the molecule $\mathrm{O}_{2}$ into atomic oxygen, while $\mathrm{Fe}_{2}\left(\mathrm{MoO}_{4}\right)_{3}$ uses this dissociative oxygen to oxidize methanol to formaldehyde. $\mathrm{MoO}_{3}$ is an active phase and restored lost Mo in the partial oxidation of methanol [69].

Bowker et al. [131] examined the interaction of methanol with novel synthesized $\mathrm{Fe}_{2} \mathrm{O}_{3}$ and $\mathrm{Fe}_{2} \mathrm{O}_{3} /$ Mo catalysts. Initially, the hematite converted the methanol to adsorbed methoxy and later oxidized it to the formate. However, the $\mathrm{Mo}$ in $\mathrm{Fe}_{2} \mathrm{O}_{3}$ made the material highly selective for formaldehyde production and blocked the formate pathway. Further- 
more, Bowker's group [44,55,70,132] concluded that the Mo impregnation $(2.2 \mathrm{Mo} / \mathrm{Fe}$ ratio) increased formaldehyde selectivity $>90 \%$ with $90 \%$ methanol conversion. After the segregation of the Mo contents, the authors noticed the sudden decline in formaldehyde selectivity, and, eventually, CO was found to be a significant product. In another study, Bowker et al. [107] used a computational approach in the continuity of his work to study iron-oxide-supported mono-, bi-, and multilayered Mo-rich surfaces in the methanol reaction. Covering a wide Mo load range, one Mo coating produced $\mathrm{CO}$ as the main product; bicharged Mo layers produced formaldehyde efficiently; furthermore, an increase in Mo content lead to the formation of formats.

Yeo et al. [32] synthesized an iron molybdenum catalyst by a physical grinding method and have found that iron molybdenum catalysts are highly selective for the oxidation of methanol to formaldehyde. Detailed surface studies have revealed that molybdenum-rich surfaces are crucial to ensure high selectivity and a large surface area.

Dias et al. [133] impregnated monolayers of $\mathrm{MoO}_{3}$ over the $\mathrm{Fe}_{2}\left(\mathrm{MoO}_{4}\right)_{3}$ and recorded that incorporating $\mathrm{MoO}_{3}$ does not affect methanol conversion and thus is not very active, but $\mathrm{MoO}_{3}$ layers with the optimal Mo content increased the yield of formaldehyde. Similarly, Pham et al. synthesized $\alpha$ and $\beta-\mathrm{MoO}_{3}$ and compared their performance. The studies confirmed that $\beta-\mathrm{MoO}_{3}$ had higher catalytic activity and selectivity for formaldehyde as compared to $\alpha-\mathrm{MoO}_{3}$. Moreover, the prepared $\beta-\mathrm{MoO}_{3}$ was active up to $320^{\circ} \mathrm{C}$ for more than $15 \mathrm{~h}$ [134].

Raun et al. [33] prepared iron molybdate loaded with the different phases (h- $\mathrm{MoO}_{3}$ $\left.\& \alpha-\mathrm{MoO}_{3}\right)$. The structure, morphology, and crystal size of the $\mathrm{MoO}_{3}$ crystal significantly affect the catalyst's durability. It is also believed that the $\mathrm{H}-\mathrm{MoO}_{3}$ immediately rearranged its phase to the $\alpha-\mathrm{MoO}_{3}$ phase and its increased stability is due to the presence of comparatively large $\mathrm{h}-\mathrm{MoO}_{3}$ crystals $(2-10 \mu \mathrm{m})$ rather than $\alpha-\mathrm{MoO}_{3}(1-2 \mu \mathrm{m})$ as given in Figure 4. While Bowker et al. highlighted the role of Mo contents on the product fraction as represented in Figure 5.

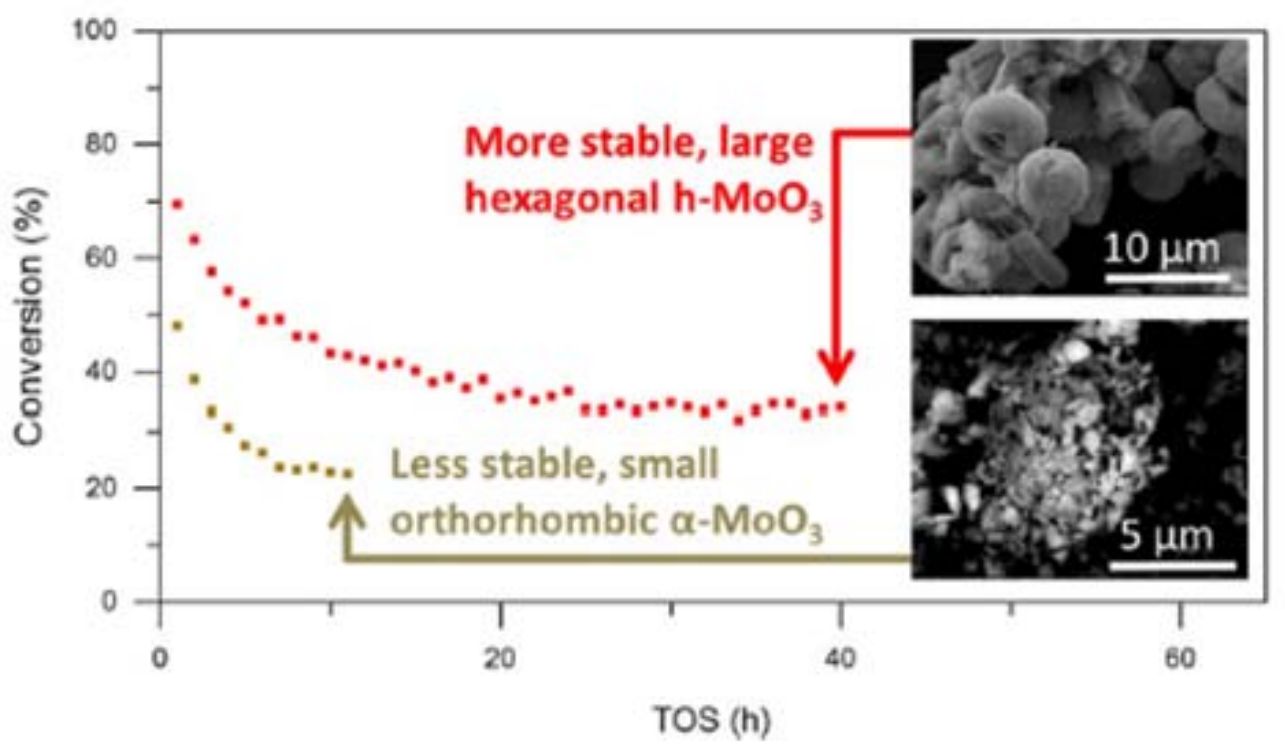

Figure 4. The detailed examination of the iron molybdate surface produced with a new physical milling method confirmed that the presence of molybdenum content affects both the structure and the catalysts' performance. Reprints from [51]. Copyright (2021), with permission from Springer Nature. 


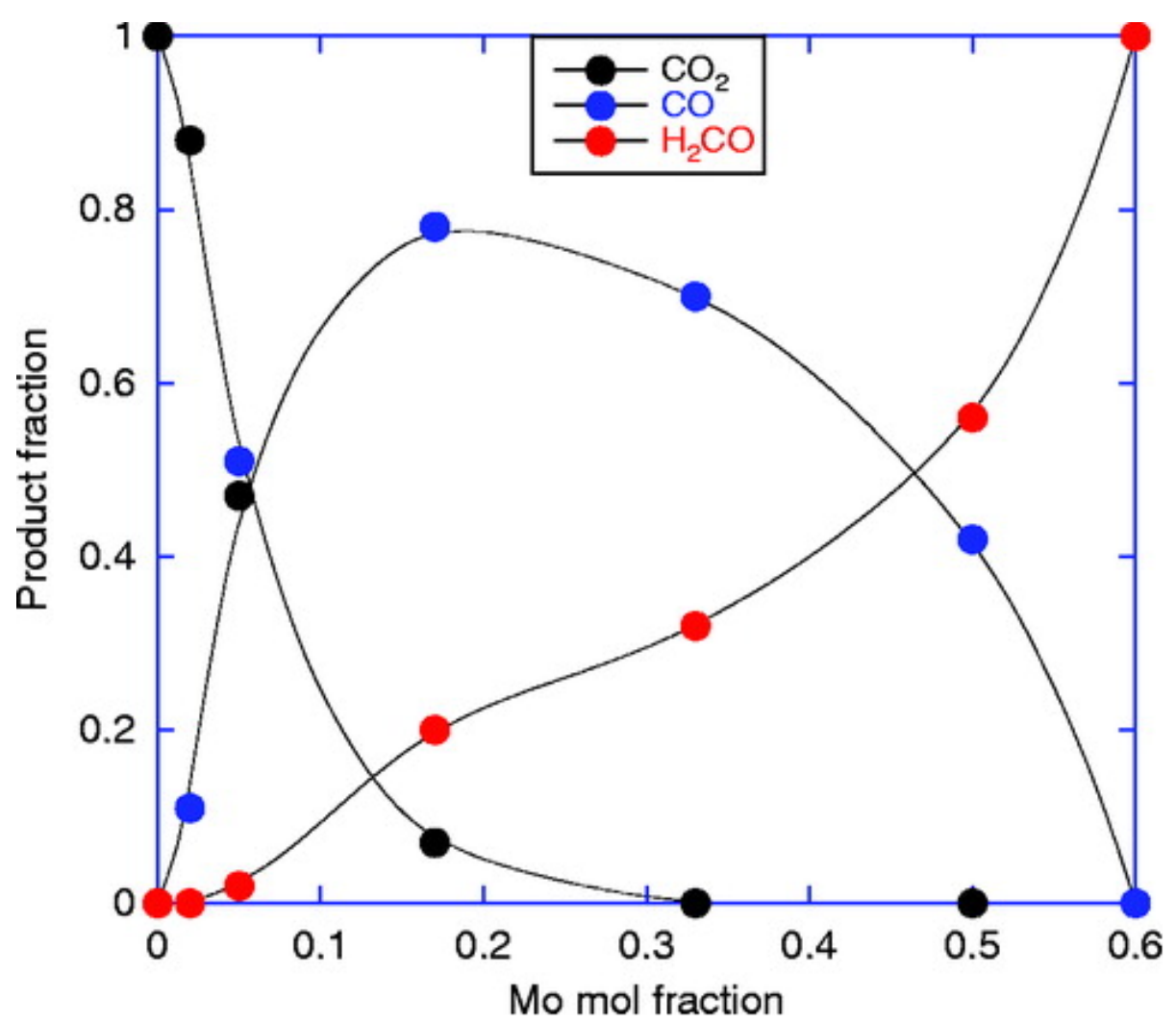

Figure 5. The product's dependence yields on Mo's mass loading. Reprint from [107]. Copyright (2021), with permission from Taylor \& Francis Online.

House et al. [44] studied the activity and selectivity of $\mathrm{Fe}_{2}\left(\mathrm{MoO}_{4}\right)_{3}$ catalysts at a Mo:Fe ratio of 0.02 to 4 in the partial oxidation of methanol. To obtain high catalytic activity and selectivity for formaldehyde, the Mo: Fe ratio should be more than 1.5. The Mo contents are believed to increase oxygen availability on the catalyst's surface and change the catalyst's acidity. As oxygen availability increases, the Mo-rich catalysts improve the surface reoxidation. Therefore, it is confirmed that excess molybdate is significant for the regeneration reaction $[55,132]$. The $\mathrm{Fe}_{2}\left(\mathrm{MoO}_{4}\right)_{3}$ acts as the acceptor. Simultaneously, the $\mathrm{MoO}_{3}$ serves as the donor phase; thus, it changes the active phase's electron density [61].

Andersson et al. prepared a novel structure (spinel-type) iron molybdate catalyst and compared its performance with traditional iron molybdate used in the partial oxidation of methanol. The spinal type had a lower Mo/Fe ratio because it could accommodate the reduced molybdenum and eventually increase the surface's reoxidized sites. The conventional type catalyst had lesser stability than spinel type and had a higher $\mathrm{Mo} / \mathrm{Fe}$ ratio [99]. The $\mathrm{Fe}_{2}\left(\mathrm{MoO}_{4}\right)_{3}$ is the active phase, and $\mathrm{MoO}_{3}$ is necessary to limit the generation of iron-rich phases and is needed to compensate for Mo's loss during the process $[34,57,59,106,110,120]$. The $\mathrm{Fe}_{2}\left(\mathrm{MoO}_{4}\right)_{3}$ acts independently with limited activity, and $\mathrm{MoO}_{3}$, a donor stage, ensures rapid oxygen availability and accelerates the entire catalytic selectivity [127].

Raun et al. [33] synthesized an iron molybdate catalyst by a hydrothermal process with an atomic ratio of $\mathrm{Mo} / \mathrm{Fe}=2$ and measured the catalyst's performance up to $600 \mathrm{~h}$, as showed in Figure 6 . During the first $10 \mathrm{~h}$, the catalyst activity decreased by $50 \%$ due to the evaporation of $\alpha-\mathrm{MoO}_{3}$. The onset of declined activity is due to decreased MoOx contents on the catalyst surface, as reported by Dias et al. [133]. 


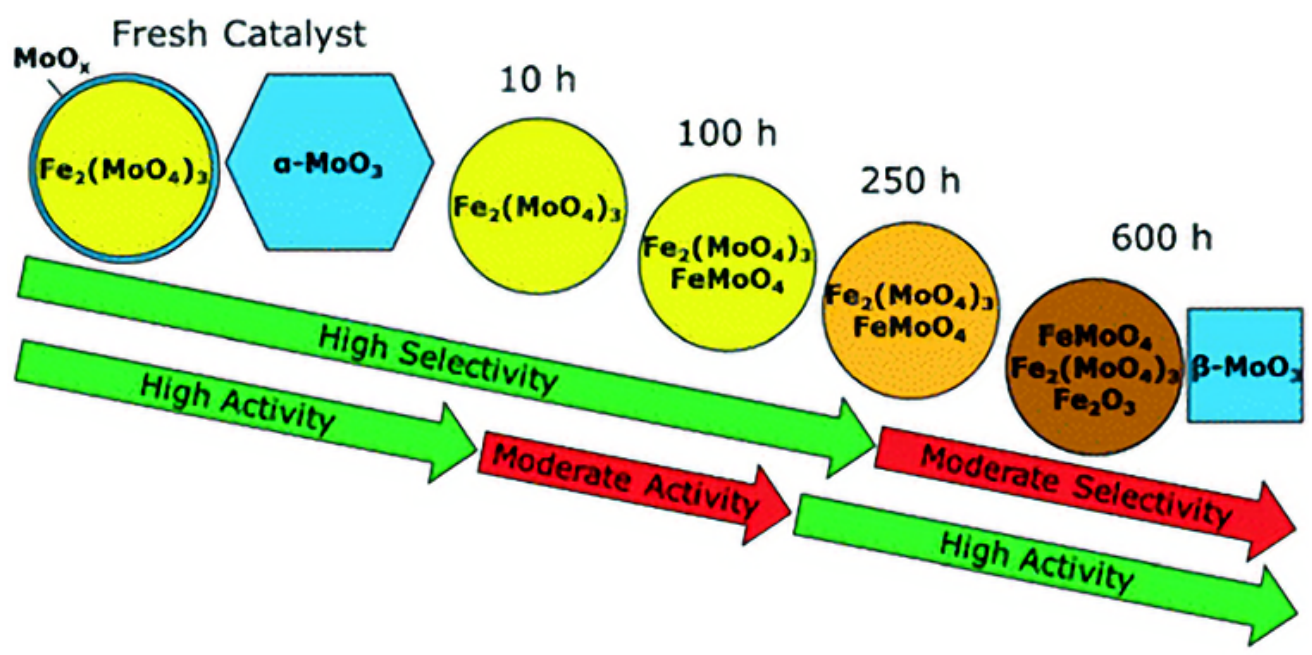

Figure 6. Deactivation behaviour of an iron molybdate catalyst during selective oxidation of methanol. Reprint from [33]. Copyright (2021), with permission from Royal Society of Chemistry.

Recently, Thrane et al. [42] confirmed the volatilization and sintering of excess molybdates at a higher temperature. The molybdates were prepared with alkali earth metals ( $\mathrm{Ba}, \mathrm{Ca}, \mathrm{Sr}$ and $\mathrm{Mg}$ ) and tested in the partial oxidation of methanol to formaldehyde. The study found the same pattern of volatilization in the prepared materials as conventional iron molybdate. The surface areas of stoichiometric molybdate were found to be higher compared with excess molybdates samples. It was confirmed that excess molybdenum was sintered and volatilized during the reaction, thus ultimately reducing the catalyst's area. The $\mathrm{MgMoO}_{4}$ was found to be active but less stable among all the tested catalysts with $75 \%$ conversion and $97 \%$ corrected selectivity at $400{ }^{\circ} \mathrm{C}$.

The Mo segregation in the iron molybdate catalyst substantially reduces the product selectivity in the partial oxidation of methanol. Therefore, it is exciting to load the Mo surface on the iron molybdate with varying combinations to study the details of catalytic activity and deactivation studies of iron molybdate catalyst. The layers of $\mathrm{MoO}_{3}$ in the $\mathrm{Fe}_{2}\left(\mathrm{MoO}_{4}\right)_{3}$ act as an active phase. Simultaneously, the crystalline excess of $\mathrm{MoO}_{3}$ is needed to compensate for the Mo volatilization in the reaction and maintain the methanol's selectivity.

\section{Role of Catalyst Support}

The selective oxidation of methanol to formaldehyde has been broadly affected by the catalytic performance and the active phase area. Machiels et al. [135] and Tatibouet et al. [1,136] synthesized $\mathrm{MoO}_{3}$ over the graphite and presented the relationships between the surface acidity and the redox sites, and obtained formaldehyde and dimethyl ether, respectively.

Castillo et al. [137] achieved $99.5 \%$ formaldehyde selectivity at $94 \%$ conversion over mechanically synthesized $\mathrm{MoO}_{3}$ and $\alpha-\mathrm{Sb}_{2} \mathrm{O}_{4}$ phases. The $\mathrm{Sb}_{2} \mathrm{O}_{4}$ was responsible for achieving high selectivity because $\mathrm{Sb}_{2} \mathrm{O}_{4}$ facilitated the reoxidation and maintained the oxygen deficiency over the catalyst surface.

Briand et al. [138] reported a relationship between activity and electronegativity of the cation on the support. The authors proposed that cation's electronegativity significantly affects electron density and the adsorption-desorption of reactants and products. It was suggested that the cation's electronegativity increases in the following order: $\mathrm{ZrO}_{2}>\mathrm{MnO}>\mathrm{TiO}_{2}>\mathrm{Nb}_{2} \mathrm{O}_{5}>\mathrm{Cr}_{2} \mathrm{O}_{3}>\mathrm{Al}_{2} \mathrm{O}_{3} \sim \mathrm{NiO}>\mathrm{SiO}_{2}$, and $\mathrm{SiO}_{2}$ supported $\mathrm{MoO}_{3}$ enhanced the activity at higher Mo coverage (high Mo density) than the lower Mo contents. The better tradeoff between the Mo contents and the electronegativity of the cation support is significant to achieve better performance (activity).

Chen and Wachs [139] synthesized the $\mathrm{MoO}_{3} / \mathrm{Ta}_{2} \mathrm{O}_{5}$ (tantalum pentoxide) catalyst and stated that the redox and acidic sites were responsible for forming formaldehyde and 
dimethyl ether, respectively. The authors noticed the distortion of the Mo species over a $1 \%$ $\mathrm{MoO}_{3}-\mathrm{Ta}_{2} \mathrm{O}_{5}$ catalyst.

Mo-Fe-O mixed oxides were also supported with different supports $\left(\mathrm{SiO}_{2}\right.$ or $\left.\mathrm{Al}_{2} \mathrm{O}_{3}\right)$ to provide adequate strength. However, the addition of supports declined the catalytic activity related to the unsupported catalyst; the drop in activity was attributed to the interaction between the support and active sites that changed the catalyst's electronic properties $[101,121,140,141]$. Moreover, the catalyst activity over the alumina supports remained constant despite the temperature rise. The silica-supported iron molybdate catalyst's selectivity decreased with increased temperature [140,142]. It is concluded that supported iron molybdate is less active than the unsupported catalyst. These results authenticated that an increase in the surface has a negative impact on iron molybdate, and these effects are more pronounced on alumina than silica. These results were also approved by Hill and Wilson [143]; when iron molybdate catalysts were synthesized on $\mathrm{SiO}_{2}, \mathrm{SiC}$ and $\mathrm{TiO}_{2}$ supports, it was concluded that Mo-Fe active sites reacted with support, and that was more evident in higher surface area materials.

Recently, Ortiz et al. [81] synthesized the iron molybdate and iron metal over the silica support and performed the partial oxidation of methane/methanol to formaldehyde. It was observed that the $\mathrm{pH}$ during synthesis significantly influenced the metal dispersion over the $\mathrm{SiO}_{2}$; this better dispersion increased the formaldehyde formation in the partial oxidation of the methane. However, the metal distribution over the silica was found not to be that active for partial oxidation of methanol. Instead, bimetallic $\mathrm{FeMoO}_{\mathrm{x}} / \mathrm{SiO}_{\mathrm{x}}$ ) prepared by the conventional sol-gel and acid-treated $\left(\mathrm{FeO}_{x} / \mathrm{SiO}_{2}\right)$ methods were found to be active in the partial oxidation of methanol to formaldehyde.

The aforementioned literature supports the idea that iron molybdate supported on the smaller surface gives better performance and activity. However, when using a low surface area material, the more the excess presence of $\mathrm{MoO}_{3}$ results in rapid volatilization [37].

Rozanov et al. $[34,144]$ concluded that the higher surface area support could enhance the catalytic activity and realized that sulphate, pyrophosphate, phosphate and chloride could have significant impacts while preparing iron molybdate over the silica. These materials may remain during the synthesis process after the calcination and increase the catalytic activity.

Similarly, in another study, Peyrovi et al. [145] synthesized the Fe-Mo catalyst over the $\gamma-\mathrm{Al}_{2} \mathrm{O}_{3}$ support prepared by impregnation and coprecipitated methods. The coprecipitated catalyst had a large particle size $(29 \mathrm{~nm})$ compared with the impregnated catalyst $(16 \mathrm{~nm})$. As a result, the coprecipitated catalyst had better performance, with $97 \%$ of methanol conversion and $96 \%$ selectivity at $350{ }^{\circ} \mathrm{C}$, with an optimum $\mathrm{Mo} / \mathrm{Fe}$ ratio of 1.7. This increased performance was attributed to the large particle size and effective contribution of the support.

Therefore, a better tradeoff between surface area, essential Mo/Fe stoichiometric ratio and the confinement effects of the support over $\mathrm{MoO}_{3}$ are vital to consider while synthesizing the iron molybdate catalyst over the different supports.

\section{Promoters}

The industrial iron molybdate catalyst's stability, mixed oxides' volatilizations, production cost, deactivation of the catalyst, mechanical abrasion of the catalyst in the reactor during repeated use, particle sintering at higher temperatures and short life (1-2 years) are significant concerns.

The promoters' addition to the iron molybdate catalyst could significantly enhance the catalyst's activity and selectivity to balance the operating cost. Not many studies have been reported on promoters in the literature. However, the addition of small amounts of chromium, aluminium, cobalt, nickel and tellurium influences the catalyst's activity and selectivity [25,146].

Klissurski et al. [147] prepared the chromium doped iron molybdate $\mathrm{Mo} /(\mathrm{Fe}+\mathrm{Cr})$ with the coprecipitation method. Chromium has increased stability and selectivity compared 
to the conventional catalyst when tested at $400-420{ }^{\circ} \mathrm{C}$ for $100 \mathrm{~h}$. The chromium-doped catalyst had constant stability over the course of $100 \mathrm{~h}$ while the traditional iron's molybdate had a $20 \%$ reduction in stability.

Sanchez et al. [148] prepared the chromium-impregnated iron molybdate catalyst by the coprecipitation method and compared its performance with industrial iron molybdate catalyst. It was observed that the addition of chromium declined the Mo/Fe atomic ratio and increased the surface area and yield compared to non-doped chromium molybdate under the same conditions.

Estevez et al. [149] recorded the chromium-based iron molybdate catalyst under various $\mathrm{Mo} / \mathrm{Fe}$ atomic ratios. The $\mathrm{Cr}$ and different $\mathrm{Mo} / \mathrm{Fe}$ atomic ratios significantly influenced and showed a higher conversion but low selectivity at the low-temperature condition. The authors argued that the rise in conversion could be due to chromium or the $\mathrm{Mo} / \mathrm{Fe}$ atomic ratios.

Pesheva et al. [150] used chromium and aluminium as promoters in the iron molybdate catalysts and recorded an improvement in the catalyst's stability. It was concluded that the promotor's reducibility is vital in the catalysts' stability and proposed the following sequence in increasing order of stability: $\mathrm{MoFeO}<\mathrm{MoFeCrO}<\mathrm{MoFeCrAlO}$

From the literature, it has been observed that the addition of $\mathrm{Cr}$ has increased the catalyst's stability and lifetime, both of which are beneficial for industrial iron molybdate catalysts.

Ivanov et al. [151] prepared the tungsten (0-15.9 wt.\%) doped iron molybdate catalyst by coprecipitation method. The prepared catalyst was subjected to reaction at $350{ }^{\circ} \mathrm{C}$ to record the formaldehyde yield. The $4.9 \mathrm{wt} . \%$ tungsten-based catalysts recorded $93.4 \%$ formaldehyde yield compared to $90.2 \%$ yield under the conventional iron molybdate catalyst. However, the deactivation mechanism was not covered in this study. The literature $[34,152]$ underlines the additional research on the $\mathrm{Sn}, \mathrm{P}, \mathrm{Mn}$ and $\mathrm{Sb}$ to investigate the regenerative, active, selective and stable promoters. The introduction of promoters during the synthesis process requires an excellent knowledge of the surface chemistry of the catalyst.

Role of Fe

Fe facilitates the transfer of $\mathrm{H}_{2} \mathrm{O}$ and $\mathrm{O}_{2}$ between the gas and the catalyst and also reoxidized reduced Mo [60]. It is believed that the iron's presence in sublayers and surface layers of iron molybdate catalyst affects both the activity and selectivity of formaldehyde. It has been concluded that iron occupancy in the sublayers of the catalyst increases the activity [25]. These results were also confirmed by Rellán-Piñeiro and López [60] using the DFT calculation and guaranteed that iron presence affects both the electronic structure and oxygen contents, thus creating the vacancies to raise the yield and selectivity of methanol. The progress in selectivity is due to the lower adsorption energy of formaldehyde than methanol. However, the iron present in the surface layers lowers the selectivity, leading to the further oxidation of the formaldehyde.

\section{Role of Oxygen}

The reaction of methanol to formaldehyde over the iron molybdate is optimally carried out from 800 to $900 \mathrm{~K}$. The oxygen availability is of utmost importance and it should be sufficiently present in the gas phase. Limited oxygen presence caused the removal of oxygen from the catalyst surface at a high temperature and left the oxidized surface to prevent methanol reduction [153].

Choksi et al. investigated lattice oxygen's interdependence on methanol oxidation and redox processes and examined methanol oxidation kinetics over oxygen at several partial pressures. The oxygen's partial pressure determines the surface's conditions; it also dramatically affects the reaction rate and changes the rate-determining step [154]. Raun et al. investigated the effects of temperature and water concentration on molybdenum loss in iron-molybdenum pellets with a molar ratio $(\mathrm{Mo} / \mathrm{Fe}=2.4)$. The optimum presence of water steam prevents Mo's evaporation and its consumption rate [52]. 
Zarei et al. [76] analyzed the functional properties, hydrodynamic effects and geometric properties of the catalyst under methanol to formaldehyde conversion. It was observed that changes in the water to methanol proportion affect and increase the conversion factor from 50.21 to 82 . Moreover, the appropriate presence of oxygen in the water selectively converts methanol to formaldehyde.

House et al. [55] highlighted the effect of oxygen on the selectivity and conversion of methanol. The oxygen content should be kept relatively high in the catalyst's bed edge to reduce the methanol and increase the selectivity to formaldehyde. The catalyst's conversion could be reduced to zero due to the loss of a significant amount of oxygen in the catalyst bed. Andersson et al. [99] highlighted the role of oxygen contents in the feed on the reaction pathway in Table 5 and proposed the highest, lowest and optimum oxygen contents required in the methanol reaction (Figure 7). If the oxygen contents are low, this will deteriorate the catalyst's surface.

Table 5. Oxygen usage per converted methanol in a $\mathrm{MoO}_{3} / \mathrm{Fe}_{2}\left(\mathrm{MoO}_{4}\right)_{3}$ system. Reprint from [99]. Copyright (2021), with permission from Springer Nature.

\begin{tabular}{cc}
\hline Reaction & Oxygen to Methanol Molar Ratio \\
\hline $\mathrm{CH}_{3} \mathrm{OH}+\frac{1}{2} \mathrm{O}_{2} \rightarrow \mathrm{CO}_{2}+2 \mathrm{H}_{2} \mathrm{O}$ & 1.5 \\
$\mathrm{CH}_{3} \mathrm{OH}+1 \mathrm{O}_{2} \rightarrow \mathrm{CO}+2 \mathrm{H}_{2} \mathrm{O}$ & 1 \\
$\mathrm{CH}_{3} \mathrm{OH}+\frac{1}{2} \mathrm{O}_{2} \rightarrow \mathrm{CH}_{2} \mathrm{O}+\mathrm{H}_{2} \mathrm{O}$ & 0.5 \\
$2 \mathrm{CH}_{3} \mathrm{OH} \rightarrow \mathrm{CH}_{3} \mathrm{O} \mathrm{CH}$ & 0 \\
$\mathrm{CH}_{2} \mathrm{O}+2 \mathrm{CH}_{2} \mathrm{O} \mathrm{OH} \rightarrow\left(\mathrm{CH}_{3} \mathrm{O}\right)_{2} \mathrm{CH}_{2}+\mathrm{H}_{2} \mathrm{O}$ & 0 \\
\hline
\end{tabular}

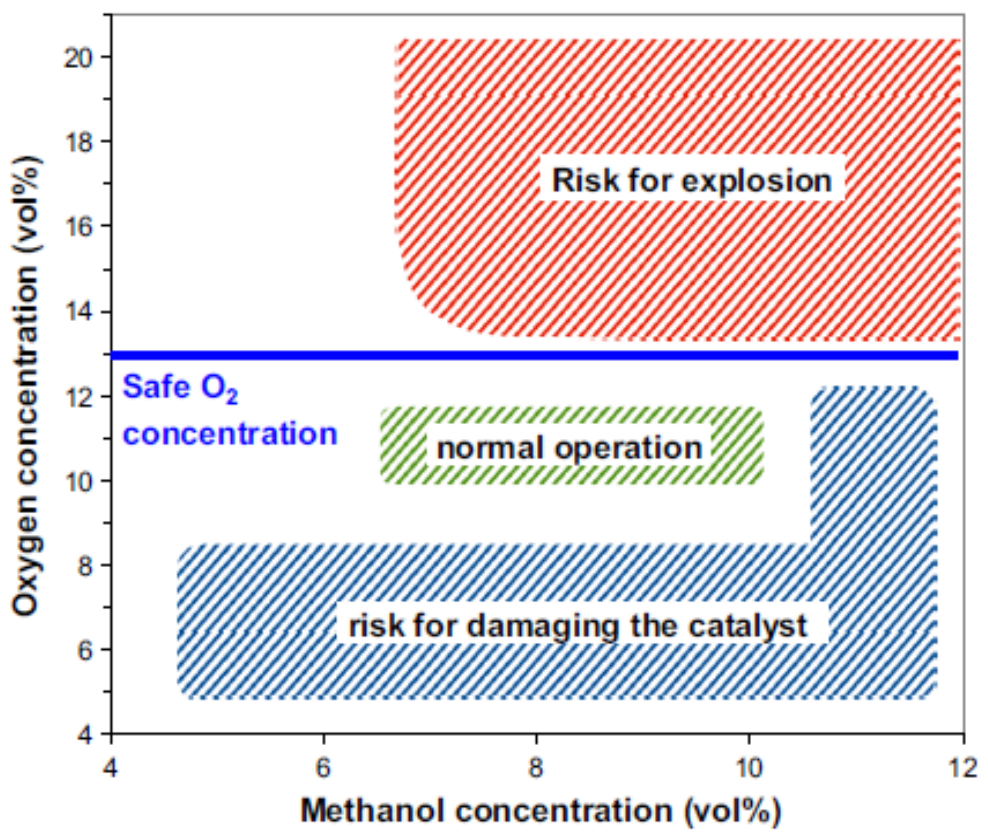

Figure 7. Feed concentration (methanol and oxygen) are presented in a small window. Reprint from [99]. Copyright (2021), with permission from Springer Nature.

While high oxygen contents could cause exposition. Therefore, an optimum presence of oxygen is required for the conversion of methanol to formaldehyde.

As from Figure 7, the reduction of the oxygen is the best way to give a larger margin to avoid the risk of explosion and damaging the catalyst. However, too low an oxygen concentration will also negatively impact the catalyst lifetime.

\section{Deactivation Studies}

When designing and developing the industrial processes, it is necessary to understand the reaction and deactivation process of the catalytic system. The iron molybdate catalyst 
has a typical operation span from 6-12 months. Thus, it is an exciting topic for researchers to study.

Ivanov et al. [155] used a pseudoisothermal reactor and investigated the iron molybdate catalyst's deactivation under $300^{\circ} \mathrm{C}$. The composition of the iron molybdate surface significantly changed after the sublimation of Mo.

Andersson et al. [99] represented the loss of Mo and V under the different molybdates and vanadates in the partial oxidation reaction (Table 6). The volatilization was analyzed after the catalyst was used for $96 \mathrm{~h}$. The reaction temperature was $300^{\circ} \mathrm{C}$.

Table 6. Volatilization of vanadium and molybdenum from a selection of vanadates and molybdates, respectively. Reprint from [99]. Copyright (2021), with permission from Springer Nature.

\begin{tabular}{cc}
\hline Catalyst & $\begin{array}{c}\text { Mo and V Loss } \\
\left(\mathbf{\%} \text { per } \mathbf{~ m}^{\mathbf{}}\right)\end{array}$ \\
\hline $\mathrm{Fe}_{2}\left(\mathrm{MoO}_{4}\right)_{3}-\mathrm{MoO}_{3}$ & 9.3 \\
$\mathrm{Fe}_{2}\left(\mathrm{MoO}_{4}\right)_{3}$ & 2.3 \\
$\mathrm{Cr}_{2}\left(\mathrm{MoO}_{4}\right)_{3}$ & 6.2 \\
$\mathrm{Zr}\left(\mathrm{MoO}_{4}\right)_{3}$ & 9.7 \\
$\mathrm{FeVO}_{4}$ & 1.9 \\
$\mathrm{AlVO}_{4}$ & 4.8 \\
$\mathrm{Mn}_{3}\left(\mathrm{VO}_{4}\right)_{2}$ & 2.9 \\
\hline
\end{tabular}

It has also been noticed that Mo condensed back as a separate layer on the catalyst surface and formed a Fe rich $(\mathrm{FeMoO})$ catalyst, which further reoxidized to the $\mathrm{Fe}_{2} \mathrm{O}_{3}$, and ultimately decreased the surface area and selectivity toward formaldehyde [106].

$$
3 \mathrm{FeMoO}_{4}+\frac{3}{4} \mathrm{O}_{2} \rightarrow \mathrm{Fe}_{2}\left(\mathrm{MoO}_{4}\right)_{3}+\frac{1}{2} \mathrm{Fe}_{2} \mathrm{O}_{3}
$$

The formation of rust (iron oxide) may stick to the reactor's metal surfaces and damage the material's durability. In addition to that, the $\mathrm{Fe}_{2} \mathrm{O}_{3}$ becomes part of the methanol feed and is oxidized with the methanol to generate heat. The excess heat resulting from $\mathrm{Fe}_{2} \mathrm{O}_{3}$ oxidization causes the deflagration of catalysts in industry [156].

Soares et al. [106] prepared the $\mathrm{Fe}_{2}\left(\mathrm{MoO}_{4}\right)_{3}$ using the coprecipitation and sol-gel method and held water responsible for deactivating the catalyst surface. The authors confirmed that the volatile $\mathrm{MoO}_{2}(\mathrm{OH})_{2}$ species formed during the reaction, which prevents reoxidation. The authors proposed that Mo volatilization is a significant cause of the deactivation of catalyst prepared by the coprecipitation method. In contrast, the sol-gel prepared catalyst deactivates primarily due to the loss of surface oxygen during the calcination. A better distribution achieved by sol-gel methods prevented the Mo volatilization and validated the presence of surface reduction in the absence of excess $\mathrm{MoO}_{3}$.

Andersson et al. [37] reported the aging and deactivation of an iron molybdate catalyst and also proposed the deactivation mechanism presented under the Equations (3)-(5) when partial oxidation of methanol is carried out under the iron molybdate catalyst.

The catalyst was entirely characterized after the complete reaction in their studies, and a significant drop in activity was recorded. The $\mathrm{MoO}_{3}$ was found to be precipitated in the same way as a needle like structure. Mo loss in the iron molybdate catalyst reduces its activity. Therefore, an excess of Mo is always needed to compensate for this loss to increase the catalyst life.

$$
\mathrm{CH}_{3} \mathrm{OH}+\mathrm{Fe}_{2}\left(\mathrm{MoO}_{4}\right)_{3} \rightarrow \mathrm{CH}_{2} \mathrm{O}+\mathrm{H}_{2} \mathrm{O}+2 \mathrm{FeMoO}_{4}+\mathrm{MoO}_{3}
$$

The excess $\mathrm{MoO}_{3}$ proceeds the reoxidation reaction as follows:

$$
2 \mathrm{FeMoO}_{4}+\mathrm{MoO}_{3}+\frac{1}{2} \mathrm{O}_{2} \rightarrow \mathrm{Fe}_{2}\left(\mathrm{MoO}_{4}\right)_{3}
$$

However, in a $\mathrm{MoO}_{3}$ deficient environment, $\mathrm{Fe}_{2} \mathrm{O}_{3}$ assists the $\mathrm{CO}_{2}$ production. As explained earlier in reaction (3) 


$$
3 \mathrm{FeMoO}_{4}+\frac{3}{4} \mathrm{O}_{2} \rightarrow \mathrm{Fe}_{2}\left(\mathrm{MoO}_{4}\right)_{3}+\frac{1}{2} \mathrm{Fe}_{2} \mathrm{O}_{3}
$$

Sun-Kou et al. [58] reported that the correct Mo: Fe ratio (1.7:1) is essential to achieve both active and stable catalysts, and excess Mo above the optimum level might not participate in the process because of the high loss rate.

Mitov et al. [157] proposed that the deactivation of the iron molybdate proceeds via anion mobility, which led to the disruption of the catalytic surface at $300{ }^{\circ} \mathrm{C}$ and disruption increase at higher temperatures. However, Jacques et al. [158] concluded that water formation during the reaction blocks the active sites and causes $\mathrm{H}$ obstruction on the surface. Jacques et al. [159] also observed the reduction in stability and performance at $350{ }^{\circ} \mathrm{C}$ when $\mathrm{MoO}_{3}$ volatilized and led to the formation of the $\mathrm{MoO}_{2}$ phase. The excess $\mathrm{MoO}_{3}$ is essential to reduce methanol and oxidized the $\mathrm{O}_{2}$ at a high rate.

The iron molybdate catalyst life also depends on temperature, pellet size, methanol to oxygen ratio and working conditions $[69,160]$. The volatile species formed in partial oxidation of methanol lead to Mo's volatilization, thus deactivating the catalyst surface $[37,106,110,160,161]$. It leads to particle sintering in high-temperature zones, increases the pressure drop and decreases catalytic activity [161-163]. The deactivation changes the iron molybdate $\mathrm{Fe}_{2}\left(\mathrm{MoO}_{4}\right)_{3}$ into the $\mathrm{Fe}_{2} \mathrm{O}_{3}$ and $\mathrm{FeMoO}_{4}$-phase $[37,106,161]$. Braz et al. also agreed that high-temperature zones in the reactor facilitate the volatilization in the partial oxidation of methanol, resulting in the loss of Mo [39].

\section{Conclusions}

Based on a review of the literature, the role of $\mathrm{MoO}_{3}$ and $\mathrm{Fe}_{2}\left(\mathrm{MoO}_{4}\right)_{3}$ has been discussed. It is concluded that the correct $\mathrm{Mo} / \mathrm{Fe}$ ratio is mandatory to achieve the selective formation of formaldehyde. $\mathrm{Fe}_{2}\left(\mathrm{MoO}_{4}\right)_{3}$ has been identified as the active ingredient, and excess molybdenum is considered a bystander phase. The optimum stoichiometric ratio $(\mathrm{Mo} / \mathrm{Fe})$ maintains oxygen availability on the catalyst's surface and affects the catalytic acidity required for the selective conversion of methanol to formaldehyde. $\mathrm{Fe}_{2}\left(\mathrm{MoO}_{4}\right)_{3}$ acts as an active phase with optimum Mo needed to compensate for the loss of molybdenum during the reaction. The presence of Mo contents maintains the electron density and serves as the donor phase. It provides the needed oxygen to support the activity and limits the generation of iron-rich phases. However, excess Mo above the optimum level might not participate in the reaction because of the high degradation rate. Similarly, different phases of $\mathrm{MoO}_{3}$, active support to maintain the electronic properties and confinement of metals, the addition of effective promoter and its reproducibility, optimum methanol to oxygen contents, synthesis methods and newly shaped catalyst particles (spinal type) compared to conventional catalysts essentially affect the conversation and selectivity in the partial oxidation of methanol. The limited supply of Mo, insufficient oxygen contents, the presence of water, high-temperature zones and methanol itself act as reducing agents and remove oxygen from the surface, leading to several deficient Mo-based iron molybdate catalysts, which are neither selective nor active towards formaldehyde.

It is crucial to consider the reaction conditions, preparation methods to influence the catalyst particle's shape $\left(\mathrm{Fe}_{2}\left(\mathrm{MoO}_{4}\right)_{3}-\mathrm{MoO}_{3}\right)$ and maintain the active $\mathrm{MoO}_{3}$ bystander for an extended period. Incorporating a computer-based simulation to accurately analyze the bonding energy between the catalyst surface and oxygen for quick reduction and fast reoxidation is essential to extend the catalyst's life and selectivity towards formaldehyde. New materials should give a better yield, be less volatile, and give consistent selectivity for repeated use.

Author Contributions: Conceptualization, N.A. and I.E.A.; resources, N.A. and I.E.A.; writing—original draft preparation, M.I.M., N.A. and I.E.A.; writing-review and editing, M.I.M.; N.A. and I.E.A.; supervision, N.A. and I.E.A.; project administration, N.A. and I.E.A.; funding acquisition, N.A. and I.E.A. All authors have read and approved the published version of the manuscript. 
Funding: The authors are indebted to the Canada Research Chairs program (CRC-2020-00142), and to the Natural Sciences and Engineering Research (NSERC) of Canada (RGPIN-2019-05783) for providing the project's funding.

Data Availability Statement: All data included in this study are available upon the permission from the publishers.

Conflicts of Interest: The authors declare no conflict of interest.

\section{References}

1. Tatibouët, J.M. Methanol oxidation as a catalytic surface probe. Appl. Catal. A Gen. 1997, 148, 213-252. [CrossRef]

2. Araya, S.S.; Liso, V.; Cui, X.; Li, N.; Zhu, J.; Sahlin, S.L.; Jensen, S.H.; Nielsen, M.P.; Kær, S.K. A Review of The Methanol Economy: The Fuel Cell Route. Energies 2020, 13, 596. [CrossRef]

3. Dalena, F.; Senatore, A.; Marino, A.; Gordano, A.; Basile, M.; Basile, A. Methanol Production and Applications: An Overview. In Methanol; Elsevier: Amsterdam, The Netherlands, 2018; pp. 3-28, ISBN 9780444640109.

4. Kajaste, R.; Hurme, M.; Oinas, P.; Kajaste, R.; Hurme, M.; Oinas, P. Methanol-Managing greenhouse gas emissions in the production chain by optimizing the resource base. AIMS Energy 2018, 6, 1074-1102. [CrossRef]

5. Hovda, K.E.; McMartin, K.; Jacobsen, D. Methanol and Formaldehyde Poisoning. In Critical Care Toxicology; Springer International Publishing: Cham, The Netherlands, 2017; pp. 1-18.

6. Shakeel, K.; Javaid, M.; Muazzam, Y.; Naqvi, S.R.; Taqvi, S.A.A.; Uddin, F.; Mehran, M.T.; Sikander, U.; Niazi, M.B.K. Performance Comparison of Industrially Produced Formaldehyde Using Two Different Catalysts. Processes 2020, 8, 571. [CrossRef]

7. Zhang, L. Introduction to Formaldehyde. In Issues in Toxicology; Royal Society of Chemistry: London, UK, 2018; Volume 2018, pp. 1-19.

8. Bahmanpour, A.M.; Hoadley, A.; Tanksale, A. Critical review and exergy analysis of formaldehyde production processes. Rev. Chem. Eng. 2014, 30, 583-604. [CrossRef]

9. Solt, P.; Konnerth, J.; Gindl-Altmutter, W.; Kantner, W.; Moser, J.; Mitter, R.; van Herwijnen, H.W.G. Technological performance of formaldehyde-free adhesive alternatives for particleboard industry. Int. J. Adhes. Adhes. 2019, 94, 99-131. [CrossRef]

10. Zhang, L. Formaldehyde: Exposure, Toxicity and Health Effects; Royal Society of Chemistry: London, UK, 2018 ; ISBN 9781788014519.

11. Partopour, B.; Dixon, A.G. Effect of particle shape on methanol partial oxidation in a fixed bed using CFD reactor modeling. AICHE J. 2020, 66, e16904. [CrossRef]

12. Heim, L.E.; Konnerth, H.; Prechtl, M.H.G. Future perspectives for formaldehyde: Pathways for reductive synthesis and energy storage. Green Chem. 2017, 19, 2347-2355. [CrossRef]

13. Alarcón, E. World Formaldehyde Production to Exceed 52 Mln Tonnes in 2017; Merchant Research \& Consulting Ltd.: Birmingham, UK, 2014.

14. Millar, G.J.; Collins, M. Industrial Production of Formaldehyde Using Polycrystalline Silver Catalyst. Ind. Eng. Chem. Res. 2017, 56, 9247-9265. [CrossRef]

15. Goon, S.; Bipasha, M.; Islam, M.S.; Hossain, M.B. Fish Marketing Status with Formalin Treatment in Bangladesh. Int. J. Public Heal. Sci. 2014, 3, 95. [CrossRef]

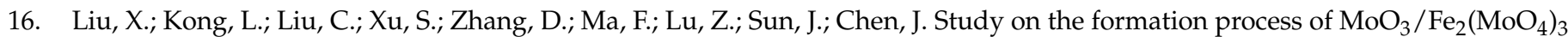
by mechanochemical synthesis and their catalytic performance in methanol to formaldehyde. J. Therm. Anal. Calorim. 2020, 142, 1363-1376. [CrossRef]

17. Abdollahi, M.; Hosseini, A. Formaldehyde. In Encyclopedia of Toxicology; Elsevier: Amsterdam, The Netherlands, 2014; pp. 653-656.

18. Subasi, N.T. Formaldehyde Advantages and Disadvantages: Usage Areas and Harmful Effects on Human Beings. In Biochemical Toxicology_Heavy Metals and Nanomaterials; IntechOpen: London, UK, 2020.

19. Jokar, S.M.; Keshavarz, M.R.; Zhubin, M.; Parvasi, P.; Basile, A. A novel tubular membrane reactor for pure hydrogen production in the synthesis of formaldehyde by the silver catalyst process. Int. J. Hydrogen Energy 2021, 46, 21953-21964. [CrossRef]

20. Maldonado, C.; Fierro, J.L.; Birke, G.; Martinez, E.; Reyes, P. Conversion of methanol to formaldehyde on $\mathrm{TiO}_{2}$ supported Ag nanoparticles. J. Chil. Chem. Soc. 2010, 55, 506-510. [CrossRef]

21. Mursics, J.; Urbancl, D.; Goricanec, D. Process of Formaldehyde and Volatile Organic Compounds' Removal fromWaste Gases. Appl. Sci. 2020, 10, 4702. [CrossRef]

22. Taylor, S. Reflections on Catalytic Selective Oxidation: Opportunities and Challenges. Catalysts 2017, 7, 34. [CrossRef]

23. Lloyd, L. Industrial Catalysts; Springer: Heidelberg, Germany, 2008; ISBN 978-0-387-24682-6.

24. Brookes, C. New Insights on the Selective Oxidation of Methanol to Formaldehyde on FeMo Based Catalysts. PhD Thesis, Cardiff University, Cardiff, UK, 2015.

25. Raun, K.V. Understanding the Deactivation of the Iron Molybdate Catalyst and its Influence on the Formox Process; Technical University of Denmark: Lyngby, Denmark, 2018.

26. Adkins, H.; Peterson, W.R. The oxidation of methanol with air over iron, molybdenum, and iron-molybdenum oxides. J. Am. Chem. Soc. 1931, 53, 1512-1520. [CrossRef]

27. Brookes, C.; Bowker, M.; Wells, P. Catalysts for the selective oxidation of methanol. Catalysts 2016, 6, 92. [CrossRef] 
28. Günther, R.; Disteldorf, W.; Gamer, A.O.; Reuss, G.; Hilt, A. Formaldehyde. In Ullmann's Encyclopedia of Industrial Chemistry; Wiley: Hoboken, NJ, USA, 2000; Volume 40, p. 34, ISBN 9783527303854.

29. Routray, K.; Zhou, W.; Kiely, C.J.; Grünert, W.; Wachs, I.E. Origin of the synergistic interaction between $\mathrm{MoO}_{3}$ and iron molybdate for the selective oxidation of methanol to formaldehyde. J. Catal. 2010, 275, 84-98. [CrossRef]

30. Dehnamaki, H.; Iranshahi, D. Simultaneous Synthesis and Oxidation of Methanol to Formaldehyde, Thermally Coupled with Cyclohexane Dehydrogenation in a Trifunctional Reactor. Energy Fuels 2019, 33, 4487-4498. [CrossRef]

31. Reuss, G.; Disteldorf, W.; Gamer, A.H. Formaldehyde Ullmann's Encyclopedia of Industrial Chemistry; Wiley-VCH: Weinheim, Germany, 2012; Volume 15.

32. Yeo, B.R.; Pudge, G.J.F.; Bugler, K.G.; Rushby, A.V.; Kondrat, S.; Bartley, J.; Golunski, S.; Taylor, S.H.; Gibson, E.; Wells, P.P.; et al. The surface of iron molybdate catalysts used for the selective oxidation of methanol. Surf. Sci. 2016, 648, 163-169. [CrossRef]

33. Raun, K.V.; Lundegaard, L.F.; Chevallier, J.; Beato, P.; Appel, C.C.; Nielsen, K.; Thorhauge, M.; Jensen, A.D.; Høj, M. Deactivation behavior of an iron-molybdate catalyst during selective oxidation of methanol to formaldehyde. Catal. Sci. Technol. 2018, 8 , 4626-4637. [CrossRef]

34. Soares, A.P.V.; Portela, M.F.; Kiennemann, A. Methanol selective oxidation to formaldehyde over Iron-Molybdate catalysts. Catal. Rev. 2005, 47, 125-174. [CrossRef]

35. Liu, X.; Kong, L.; Xu, S.; Liu, C.; Ma, F. Modified iron-molybdate catalysts with various metal oxides by a mechanochemical method: Enhanced formaldehyde yield in methanol partial oxidation. Front. Chem. Sci. Eng. 2021, 1-12. [CrossRef]

36. Matthey, J. A Formaldehyde Magazine from Johnson Matthey-The FORMOX Process. Informal Speaking. Available online: https://matthey.com/en (accessed on 22 July 2016).

37. Andersson, A.; Hernelind, M.; Augustsson, O. A study of the ageing and deactivation phenomena occurring during operation of an iron molybdate catalyst in formaldehyde production. Catal. Today 2006, 112, 40-44. [CrossRef]

38. Bahmanpour, A.M.; Hoadley, A.; Mushrif, S.H.; Tanksale, A. Hydrogenation of carbon monoxide into formaldehyde in liquid media. ACS Sustain. Chem. Eng. 2016, 4, 3970-3977. [CrossRef]

39. Braz, C.G.; Mendes, A.; Rocha, J.; Alvim, R.; Matos, H.A. Model of an industrial multitubular reactor for methanol to formaldehyde oxidation in the presence of catalyst deactivation. Chem. Eng. Sci. 2019, 195, 347-355. [CrossRef]

40. Zhang, S.; Han, M. Effect of Mo Dispersion on the Catalytic Properties and Stability of Mo-Fe Catalysts for the Partial Oxidation of Methanol. Molecules 2020, 25. [CrossRef]

41. Gaur, A.; Schumann, M.; Raun, K.V.; Stehle, M.; Beato, P.; Jensen, A.D.; Grunwaldt, J.-D.; Høj, M. Operando XAS/XRD and Raman Spectroscopic Study of Structural Changes of the Iron Molybdate Catalyst during Selective Oxidation of Methanol. ChemCatChem 2019, 11, 4871-4883. [CrossRef]

42. Thrane, J.; Lundegaard, L.F.; Beato, P.; Mentzel, U.V.; Thorhauge, M.; Jensen, A.D.; Høj, M. Alkali Earth Metal Molybdates as Catalysts for the Selective Oxidation of Methanol to Formaldehyde-Selectivity, Activity, and Stability. Catalysts 2020, 10, 82. [CrossRef]

43. Brookes, C.; Bowker, M.; Gibson, E.K.; Gianolio, D.; Mohammed, K.M.H.; Parry, S.; Rogers, S.M.; Silverwood, I.P.; Wells, P.P. In situ spectroscopic investigations of $\mathrm{MoO}_{\mathrm{x}} / \mathrm{Fe}_{2} \mathrm{O}_{3}$ catalysts for the selective oxidation of methanol. Catal. Sci. Technol. 2016, 6, 722-730. [CrossRef]

44. House, M.P.; Carley, A.F.; Echeverria-Valda, R.; Bowker, M. Effect of varying the cation ratio within iron molybdate catalysts for the selectivev oxidation of methanol. J. Phys. Chem. C 2008, 112, 4333-4341. [CrossRef]

45. Kim, T.H.; Ramachandra, B.; Choi, J.S.; Saidutta, M.B.; Choo, K.Y.; Song, S.D.; Rhee, Y.W. Selective oxidation of methanol to formaldehyde using modified iron-molybdate catalysts. Catal. Lett. 2004, 98, 161-165. [CrossRef]

46. Pernicone, N. Deactivation of Fe-Mo oxide catalyst in industrial plant and simulation tests on laboratory scale. Catal. Today 1991, 11, 85-91. [CrossRef]

47. Brookes, C.; Wells, P.P.; Dimitratos, N.; Jones, W.; Gibson, E.K.; Morgan, D.J.; Cibin, G.; Nicklin, C.; Mora-Fonz, D.; Scanlon, D.O.; et al. The Nature of the Molybdenum Surface in Iron Molybdate. The Active Phase in Selective Methanol Oxidation. J. Phys. Chem. C 2014, 118, 26155-26161. [CrossRef]

48. Gaur, A.; Stehle, M.; Raun, K.V.; Thrane, J.; Jensen, A.D.; Grunwaldt, J.-D.; Høj, M. Structural dynamics of an iron molybdate catalyst under redox cycling conditions studied with in situ multi edge XAS and XRD. Phys. Chem. Chem. Phys. 2020, $22,11713$. [CrossRef] [PubMed]

49. Nikolenko, N.V.; Kosynyuk, A.O.; Kalashnikov, Y.V.; Cheremis, E.A. The calculation of the thermodynamic equilibrium in $\mathrm{Fe}^{3+} / \mathrm{MoO}_{4}{ }^{2-} / \mathrm{H}^{+}\left(\mathrm{OH}^{-}\right) / \mathrm{H}_{2} \mathrm{O}$ system and determination of reasonable conditions for iron molybdate deposition. Russ. J. Appl. Chem. 2012, 85, 1814-1819. [CrossRef]

50. Nikolenko, N.V.; Kozhevnikov, I.V.; Kostyniuk, A.O.; Bayahia, H.; Kalashnykov, Y.V. Preparation of iron molybdate catalysts for methanol to formaldehyde oxidation based on ammonium molybdoferrate(II) precursor. J. Saudi Chem. Soc. 2018, 22, 372-379. [CrossRef]

51. Raun, K.V.; Lundegaard, L.F.; Beato, P.; Appel, C.C.; Nielsen, K.; Thorhauge, M.; Schumann, M.; Jensen, A.D.; Grunwaldt, J.D.; Høj, M. Stability of Iron-Molybdate catalysts for selective oxidation of methanol to formaldehyde: Influence of preparation method. Catal. Lett. 2020, 150. [CrossRef] 
52. Raun, K.V.; Johannessen, J.; McCormack, K.; Appel, C.C.; Baier, S.; Thorhauge, M.; Høj, M.; Jensen, A.D. Modeling of the molybdenum loss in iron molybdate catalyst pellets for selective oxidation of methanol to formaldehyde. Chem. Eng. J. 2019, 361, 1285-1295. [CrossRef]

53. Deshmukh, S.A.R.K.; Van Sint Annaland, M.; Kuipers, J.A.M. Kinetics of the partial oxidation of methanol over a Fe-Mo catalyst. Appl. Catal. A Gen. 2005, 289, 240-255. [CrossRef]

54. Raun, K.V.; Thorhauge, M.; Høj, M.; Jensen, A.D. Modeling of molybdenum transport and pressure drop increase in fixed bed reactors used for selective oxidation of methanol to formaldehyde using iron molybdate catalysts. Chem. Eng. Sci. 2019, 202, 347-356. [CrossRef]

55. House, M.P.; Carley, A.F.; Bowker, M. Selective oxidation of methanol on iron molybdate catalysts and the effects of surface reduction. J. Catal. 2007, 252, 88-96. [CrossRef]

56. Uhlrich, J.J.; Sainio, J.; Lei, Y.; Edwards, D.; Davies, R.; Bowker, M.; Shaikhutdinov, S.; Freund, H.J. Preparation and characterization of iron-molybdate thin films. Surf. Sci. 2011, 605, 1550-1555. [CrossRef]

57. Okamoto, Y.; Morikawa, F.; Oh-Hiraki, K.; Imanaka, T.; Teranishi, S. Role of excess of $\mathrm{MoO}_{3}$ in $\mathrm{Fe}_{2} \mathrm{O}_{3}-\mathrm{MoO}_{3}$ methanol oxidation catalysts studied by X-ray photoelectron spectroscopy. J. Chem. Soc. Chem. Commun. 1981, 1018-1019. [CrossRef]

58. Sun-Kou, M.R.; Mendioroz, S.; Fierro, J.L.G.; Palacios, J.M.; Guerrero-Ruiz, A. Influence of the preparation method on the behaviour of Fe-Mo catalysts for the oxidation of methanol. J. Mater. Sci. 1995, 30, 496-503. [CrossRef]

59. Bowker, M.; Holroyd, R.; Elliott, A.; Morrall, P.; Alouche, A.; Entwistle, C.; Toerncrona, A. The selective oxidation of methanol to formaldehyde on iron molybdate catalysts and on component oxides. Catal. Lett. 2002, 83, 165-176. [CrossRef]

60. Rellán-Piñeiro, M.; López, N. The Active molybdenum oxide phase in the methanol oxidation to formaldehyde (formox process): A DFT study. ChemSusChem 2015, 8, 2231-2239. [CrossRef] [PubMed]

61. Oudghiri-Hassani, H. Synthesis, characterization and catalytic performance of iron molybdate $\mathrm{Fe}_{2}\left(\mathrm{MoO}_{4}\right)_{3}$ nanoparticles. Catal Commun. 2015, 60, 19-22. [CrossRef]

62. Thavornprasert, K.; Capron, M.; Jalowiecki-Duhamel, L.; Gardoll, O.; Trentesaux, M.; Mamede, A.S.; Fang, G.; Faye, J.; Touati, N.; Vezin, H.; et al. Highly productive iron molybdate mixed oxides and their relevant catalytic properties for direct synthesis of 1,1-dimethoxymethane from methanol. Appl. Catal. B Environ. 2014, 145, 126-135. [CrossRef]

63. Pradhan, S.; Bartley, J.K.; Bethell, D.; Carley, A.F.; Conte, M.; Golunski, S.; House, M.P.; Jenkins, R.L.; Lloyd, R.; Hutchings, G.J. Non-lattice surface oxygen species implicated in the catalytic partial oxidation of decane to oxygenated aromatics. Nat. Chem. 2012, 4, 134-139. [CrossRef] [PubMed]

64. Nisar, J.; Hassan, S.; Khan, M.I.; Iqbal, M.; Nazir, A.; Sharif, A.; Ahmed, E. Hetero-structured Iron Molybdate Nanoparticles: Synthesis, Characterization and Photocatalytic Application. Int. J. Chem. React. Eng. 2020, 18. [CrossRef]

65. Wang, Y.; He, P.; Lei, W.; Dong, F.; Zhang, T. Novel FeMoO4/graphene composites based electrode materials for supercapacitors. Compos. Sci. Technol. 2014, 103, 16-21. [CrossRef]

66. Barik, R.; Mukherjee, P.; Sahu, K.K.; Sanjay, K.; Ghosh, M.K.; Mohapatra, M. Synthesis of iron molybdate from molybdenum spent catalyst and evaluation of its electrochemical properties. Environ. Prog. Sustain. Energy 2021, 40, e13560. [CrossRef]

67. Belhekar, A.A.; Ayyappan, S.; Ramaswamy, A.V. FT-IR studies on the evolution of different phases and their interaction in ferric molybdate-Molybdenum trioxide catalysts. J. Chem. Technol. Biotechnol. 1994, 59, 395-402. [CrossRef]

68. Machiels, C.J.; Sleight, A.W. Kinetic isotope effect in the selective oxidation of methanol to formaldehyde over some molybdate catalysts. J. Catal. 1982, 76, 238-239. [CrossRef]

69. Söderhjelm, E.; House, M.P.; Cruise, N.; Holmberg, J.; Bowker, M.; Bovin, J.-O.; Andersson, A. On the Synergy Effect in $\mathrm{MoO}_{3}-\mathrm{Fe}_{2}\left(\mathrm{MoO}_{4}\right)_{3}$ Catalysts for Methanol Oxidation to Formaldehyde. Top. Catal. 2008, 50, 145-155. [CrossRef]

70. Brookes, C.; Wells, P.P.; Cibin, G.; Dimitratos, N.; Jones, W.; Morgan, D.J.; Bowker, M. Molybdenum oxide on Fe $\mathrm{O}_{3}$ core-shell catalysts: Probing the nature of the structural motifs responsible for methanol oxidation catalysis. ACS Catal. 2014, 4, 243-250. [CrossRef]

71. Wang, C.T.; Willey, R.J. Oxidation of methanol over iron oxide based aerogels in supercritical CO 2 . J. Non. Cryst. Solids 1998, 225, 173-177. [CrossRef]

72. Garba Wawata, I. Methanol Oxidation on Molybdenum Oxide Catalysts; Cardiff University: Cardiff, UK, 2015.

73. Bowker, M.; Carley, A.F.; House, M. Contrasting the behaviour of $\mathrm{MoO}_{3}$ and $\mathrm{MoO}_{2}$ for the oxidation of methanol. Catal. Letters 2008, 120, 34-39. [CrossRef]

74. Carbucicchio, M.; Trifirò, F. Surface and bulk redox processes in iron-molybdate-based catalysts. J. Catal. 1976, 45, 77-85. [CrossRef]

75. Price, S. Catalytic Oxidation of Methanol to Formaldehyde by Mass-Selected Vanadium Oxide Clusters Supported on a TiO 2 (110) Surface. J. Phys. Chem. 2014, 118, 8309. [CrossRef] [PubMed]

76. Zarei, M.; Davarpanah, A.; Mokhtarian, N.; Farahbod, F. Integrated feasibility experimental investigation of hydrodynamic, geometrical and, operational characterization of methanol conversion to formaldehyde. Int. J. Ambient. Energy 2018, 42, 89-103. [CrossRef]

77. Inokawa, H.; Zaman, S.F.; Driss, H.; Daous, M.; Al-Zahrani, A.; Miyaoka, H.; Ichikawa, T.; Kojima, Y.; Petrov, L.A. Formaldehyde production via partial oxidation of methanol over oxides of $\mathrm{Cr}$, Mo and W supported on ceria-zirconia. IOP Conf. Ser. Mater. Sci. Eng. 2018, 458, 012018. [CrossRef] 
78. Hou, X.X.; Xu, C.H.; Liu, Y.L.; Li, J.J.; Hu, X.D.; Liu, J.; Liu, J.Y.; Xu, Q. Improved methanol synthesis from $\mathrm{CO}_{2}$ hydrogenation over CuZnAlZr catalysts with precursor pre-activation by formaldehyde. J. Catal. 2019, 379, 147-153. [CrossRef]

79. Xiao, Y.; Wang, Y.; Varma, A. Low-temperature selective oxidation of methanol over Pt-Bi bimetallic catalysts. J. Catal. 2018, 363, 144-153. [CrossRef]

80. Chen, D.; Qu, Z.; Shen, S.; Li, X.; Shi, Y.; Wang, Y.; Fu, Q.; Wu, J. Comparative studies of silver based catalysts supported on different supports for the oxidation of formaldehyde. Catal. Today 2011, 175, 338-345. [CrossRef]

81. Cortés Ortiz, W.G.; Delgado, D.; Guerrero Fajardo, C.A.; Agouram, S.; Sanchís, R.; Solsona, B.; López Nieto, J.M. Partial oxidation of methane and methanol on $\mathrm{FeO}_{\mathrm{x}^{-}}, \mathrm{MoO}_{\mathrm{x}}$ - and $\mathrm{FeMoO}_{\mathrm{x}}-\mathrm{SiO}_{2}$ catalysts prepared by sol-gel method: A comparative study. Mol. Catal. 2020, 491, 110982. [CrossRef]

82. Marcinkowski, M.D.; Yuk, S.F.; Doudin, N.; Smith, R.S.; Nguyen, M.T.; Kay, B.D.; Glezakou, V.A.; Rousseau, R.; Dohnálek, Z Low-Temperature Oxidation of Methanol to Formaldehyde on a Model Single-Atom Catalyst: Pd Atoms on $\mathrm{Fe}_{3} \mathrm{O}_{4}(001)$. ACS Catal. 2019, 10977-10982. [CrossRef]

83. Matthey, J. A Formaldehyde Magazine from Johnson Matthey-The FORMOX Process. Informal Speaking. Available online: https:/ / matthey.com/en (accessed on 22 July 2020).

84. Häggblad, R.; Wagner, J.B.; Hansen, S.; Andersson, A. Oxidation of methanol to formaldehyde over a series of $\mathrm{Fe}_{1-\mathrm{x}} \mathrm{Al}_{\mathrm{x}}-\mathrm{V}-\mathrm{oxide}$ catalysts. J. Catal. 2008, 258, 345-355. [CrossRef]

85. Grasselli, R.K.; Lugmair, C.G.; Volpe, A.F. Towards an Understanding of the Reaction Pathways in Propane Ammoxidation Based on the Distribution of Elements at the Active Centers of the M1 Phase of the MoV(Nb,Ta)TeO System. Top. Catal. 2011, 54, 595-604. [CrossRef]

86. Duprez, D.; Cavani, F. Handbook of Advanced Methods and Processes in Oxidation Catalysis: From Laboratory to Industry; Imperial College Press: London, UK, 2014; ISBN 9781848167513.

87. Lintz, H.-G.; Müller, S.P. The partial oxidation of propane on mixed metal oxides-A short overview. Appl. Catal. A Gen. 2009, 357, 178-183. [CrossRef]

88. Liu, Y.M.; Feng, W.L.; Li, T.C.; He, H.Y.; Dai, W.L.; Huang, W.; Cao, Y.; Fan, K.N. Structure and catalytic properties of vanadium oxide supported on mesocellulous silica foams (MCF) for the oxidative dehydrogenation of propane to propylene. J. Catal. 2006, 239, 125-136. [CrossRef]

89. Rosowski, F.; Altwasser, S.; Dobner, C.K.; Storck, S.; Zühlke, J.; Hibst, H. New silver- and vanadium-containing multimetal oxides for oxidation of aromatic hydrocarbons. In Proceedings of the Catalysis Today; Elsevier: Amsterdam, The Netherlands, 2010; Volume 157, pp. 339-344.

90. Rebsdat, S.; Mayer, D. Ethylene Oxide. In Ullmann's Encyclopedia of Industrial Chemistry; Wiley-VCH Verlag GmbH \& Co. KGaA: Weinheim, Germany, 2001; p. 26.

91. Grasselli, R.K.; Buttrey, D.J.; DeSanto, P.; Burrington, J.D.; Lugmair, C.G.; Volpe, A.F.; Weingand, T. Active centers in $\mathrm{Mo}-\mathrm{V}-\mathrm{Nb}-\mathrm{Te}-\mathrm{O}$ (amm)oxidation catalysts. In Proceedings of the Catalysis Today; Elsevier: Amsterdam, The Netherlands, 2004; Volume 91-92, pp. 251-258.

92. Mistry, C.R.; Mewada, R.K.; Srivastava, V.; Jasra, R. Characteristics of Oxidation and Oxidative Dehydrogenation Catalysts for Gas Phase Reactions: A Review. In Proceedings of the Nirma University International Conference on Engineering (Nuicone), Ahmedabad, India, 8-10 December 2011.

93. Riittonen, T.; Toukoniitty, E.; Madnani, D.K.; Leino, A.R.; Kordas, K.; Szabo, M.; Sapi, A.; Arve, K.; Wärnå, J.; Mikkola, J.P. One-pot liquid-phase catalytic conversion of ethanol to 1-butanol over aluminium oxide-the effect of the active metal on the selectivity. Catalysts 2012, 2, 68-84. [CrossRef]

94. Védrine, J. Heterogeneous Partial (amm)Oxidation and Oxidative Dehydrogenation Catalysis on Mixed Metal Oxides. Catalysts 2016, 6, 22. [CrossRef]

95. Arntz, D.; Fischer, A.; Höpp, M.; Jacobi, S.; Sauer, J.; Ohara, T.; Sato, T.; Shimizu, N.; Schwind, H. Acrolein and Methacrolein. In Ullmann's Encyclopedia of Industrial Chemistry; Wiley-VCH Verlag GmbH \& Co. KGaA: Weinheim, Germany, 2012.

96. Cavani, F. Catalytic selective oxidation: The forefront in the challenge for a more sustainable chemical industry. Catal. Today 2010, 157, 8-15. [CrossRef]

97. Whiting, G.T.; Bartley, J.K.; Dummer, N.F.; Hutchings, G.J.; Taylor, S.H. Vanadium promoted molybdenum phosphate catalysts for the vapour phase partial oxidation of methanol to formaldehyde. Appl. Catal. A Gen. 2014, 485, 51-57. [CrossRef]

98. Laitinen, T.; Ojala, S.; Cousin, R.; Koivikko, N.; Poupin, C.; El Assal, Z.; Aho, A.; Keiski, R.L. Activity, selectivity, and stability of vanadium catalysts in formaldehyde production from emissionsof volatile organic compounds. J. Ind. Eng. Chem. 2020, 83, 375-386. [CrossRef]

99. Andersson, A.; Holmberg, J.; Häggblad, R. Process improvements in methanol oxidation to formaldehyde: Application and catalyst development. Top. Catal. 2016, 59, 1589-1599. [CrossRef]

100. Matthey, J. A Formaldehyde Magazine from Johnson Matthey-The FORMOX Process. Informal Speaking. Available online: https: / / matthey.com/en (accessed on 22 July 2019).

101. Group, F. Some aspects of a newly developed Fe-Mo/SiO2 oxide for methanol oxidation in a fluidized Bed. Sci. Sin. Chang. Inst. Appl. Chem. 1979, XXII, 777.

102. Cairati, L.; Di Flore, L.; Forzatti, P.; Pasquen, I.; Trifirò, F. Oxidation of methanol in a fluidized Bed. 1. catalyst attrition resistance and process variable study. Ind. Eng. Chem. Process Des. Dev. 1980, 19, 561-565. [CrossRef] 
103. Pernicone, N. MoO3Fe2(MoO4)3 catalysts for methanol oxidation. J. Less-Common Met. 1974, 36, 289-297. [CrossRef]

104. Hassan, K.H.; Mitchell, P.C.H. Evaluation of different methods to prepare the Fe2O3/MoO3 catalyst used for selective oxidation of methanol to formaldehyde. Stud. Surf. Sci. Catal. 2010, 175, 475-478. [CrossRef]

105. Chapman, S.; Brookes, C.; Bowker, M.; Gibson, E.K.; Wells, P.P. Design and stabilisation of a high area iron molybdate surface for the selective oxidation of methanol to formaldehyde. Faraday Discuss. 2016, 188, 115-129. [CrossRef]

106. Soares, A.P.V.; Portela, M.F.; Kiennemann, A.; Hilaire, L. Mechanism of deactivation of iron-molybdate catalysts prepared by coprecipitation and sol-gel techniques in methanol to formaldehyde oxidation. Chem. Eng. Sci. 2003, 58, 1315-1322. [CrossRef]

107. Bowker, M.; House, M.; Alshehri, A.; Brookes, C.; Gibson, E.K.; Wells, P.P. Selectivity determinants for dual function catalysts: Applied to methanol selective oxidation on iron molybdate. Catal. Struct. React. 2015, 1. [CrossRef]

108. Wang, C.-T.; Willey, R.J. Mechanistic aspects of methanol partial oxidation over supported iron oxide aerogels. J. Catal. 2001, 202. [CrossRef]

109. Bowker, M.; Holroyd, R.; House, M.; Bracey, R.; Bamroongwongdee, C.; Shannon, M.; Carley, A. The Selective Oxidation of Methanol on Iron Molybdate Catalysts. Top. Catal. 2008, 48, 158-165. [CrossRef]

110. Soares, A.P.V.; Farinha Portela, M.; Kiennemann, A.; Hilaire, L.; Millet, J.M.M. Iron molybdate catalysts for methanol to formaldehyde oxidation: Effects of Mo excess on catalytic behaviour. Appl. Catal. A Gen. 2001, 206, 221-229. [CrossRef]

111. Beale, A.M.; Jacques, S.D.M.; Sacaliuc-Parvalescu, E.; O’Brien, M.G.; Barnes, P.; Weckhuysen, B.M. An iron molybdate catalyst for methanol to formaldehyde conversion prepared by a hydrothermal method and its characterization. Appl. Catal. A Gen. 2009, 363, 143-152. [CrossRef]

112. Jin, G.; Weng, W.; Lin, Z.; Dummer, N.F.; Taylor, S.H.; Kiely, C.J.; Bartley, J.K.; Hutchings, G.J. Fe2(MoO4)3/MoO3 nano-structured catalysts for the oxidation of methanol to formaldehyde. J. Catal. 2012, 296, 55-64. [CrossRef]

113. Soares, A.P.V.; Portela, M.F.; Kiennemann, A. A comparison of iron molybdate catalysts for methanol oxidation prepared by copreciptation and new sol-gel method. Stud. Surf. Sci. Catal. 1997, 110, 807-816. [CrossRef]

114. Li, J.L.; Zhang, Y.X.; Liu, C.W.; Zhu, Q.M. Improvement in reactivity, reproducibility and stability of Fe-Mo catalysts by wet mixing. Catal. Today 1999, 51, 195-199. [CrossRef]

115. Popov, B.I.; Shkuratova, L.N.; Skorokhova, N.G. Influence of sodium salts on the catalytic properties of iron-molybdenum oxide catalysts in the oxidation of methanol to formaldehyde. React. Kinet. Catal. Lett. 1975, 3, 463-469. [CrossRef]

116. Burcham, L.J.; Briand, L.E.; Wachs, I.E. Quantification of active sites for the determination of methanol oxidation turn-over frequencies using methanol chemisorption and in situ infrared techniques. 1: Supported metal oxide catalysts. Langmuir 2001, 17, 6164-6174. [CrossRef]

117. Demidov, A.; Danilova, I.; Kustova, G.; Plyasova, L.; Skomorokhova, N.; Sedova, L.; Nakrokhin, V.; Popov, B. Effect of anions on the catalytic properties of ferric molybdate in the selective oxidation of methanol. Kinet. Catal. 1992, 33, 910-914.

118. Kong, L.; Zhang, M.; Liu, X.; Ma, F.; Wei, B.; Wumaier, K.; Zhao, J.; Lu, Z.; Sun, J.; Chen, J.; et al. Green and rapid synthesis of iron molybdate catalyst by mechanochemistry and their catalytic performance for the oxidation of methanol to formaldehyde. Chem. Eng. J. 2019, 364, 390-400. [CrossRef]

119. Alessandrini, G.; Cairati, L.; Forzatti, P.; Villa, P.L.; Trifirò, F. Chemical, structural and catalytic modifications of pure and doped iron(III) molybdate. J. Less-Common Met. 1977, 54, 373-386. [CrossRef]

120. Kolovertnov, G.D.; Boreskov, G.K.; Dzisko, V.A.; Popov, B.I.; Tarasova, D.V.; Belugina, G.C. Study on iron-molybdenum oxide catalysts for the oxidation of methanol to formaldehyde. I. Specific activity as a function of the catalyst composition. Kinet. Catal. Engl. Transl. 1965, 6, 950.

121. Wilson, J.H. Raman Spectroscopic Studies of Iron/Molybdenum Oxide Catalysts for the Oxidation of Methanol to Formaldehyde; University of Wisconsin: Madison, WI, USA, 1986; Volume 1.

122. Farneth, W.E.; Ohuchi, F.; Staley, R.H.; Chowdhry, U.; Sleight, A.W. Mechanism of partial oxidation of methanol over MoO 3 as studied by temperature-programmed desorption. J. Phys. Chem. 1985, 89, 2493-2497. [CrossRef]

123. Boreskov, G.K.; Kolovertnov, G.D.; Kefeli, L.M.; Plyasova, L.M.; Karakchiev, L.G.; Mastikhin, V.N.; Popov, V.I.; Dzis'Ko, V.A.; Tarasova, D.V. Study of an Iron-Molybdenum Oxide Catalyst for the Oxidation of Methanol to Formaldehyde. II. Phase Composition and Nature of the Catalytically Active Component. Kinet. Catal. Engl.Transl. 1966, 7, 125-130.

124. Chowdhry, U.; Ferretti, A.; Firment, L.E.; Machiels, C.J.; Ohuchi, F.; Sleight, A.W.; Staley, R.H. Mechanism and surface structural effects in methanol oxidation over molybdates. Appl. Surf. Sci. 1984, 19, 360-372. [CrossRef]

125. Weckhuysen, B.M.; Wachs, I.E. The Role of Terminal M55O Bonds in Selective Oxidation Reactions Over Metal Oxide Catalysts. In Proceedings of the 11th International Congress on Catalysis-40th Anniversary, Baltimore, MD, USA, 30 June-5 July 1996.

126. Truong, V.; Nguyen, V.P.L.; Tittarelli, P. Bulk and Surface Characterization of Iron (III) Molybdate Catalysts for the Oxidation of Methanol. Chemistry and Uses of Molybdenum. In Proceedings of the Third International Conference, Ann Arbor, MI, USA, 19-23 August 1979; p. 161.

127. Wachs, I.E.; Routray, K. Catalysis Science of Bulk Mixed Oxides. ACS Catal. 2012, 2, 1235-1246. [CrossRef]

128. Chung, J.S.; Miranda, R.; Bennett, C.O. Mechanism of partial oxidation of methanol over MoO3. J. Catal. 1988, 114, 398-410. [CrossRef]

129. Meng, Y.; Wang, T.; Chen, S.; Zhao, Y.; Ma, X.; Gong, J. Selective oxidation of methanol to dimethoxymethane on $\mathrm{V}_{2} \mathrm{O}_{5}-\mathrm{MoO}_{3} / \gamma-$ $\mathrm{Al}_{2} \mathrm{O}_{3}$ catalysts. Appl. Catal. B Environ. 2014, 160-161, 161-172. [CrossRef] 
130. Huang, P.R.; He, Y.; Cao, C.; Lu, Z.H. Impact of lattice distortion and electron doping on $\alpha-\mathrm{MoO}_{3}$ electronic structure. Sci. Rep. 2014, 4. [CrossRef] [PubMed]

131. Bowker, M.; Gibson, E.K.; Silverwood, I.P.; Brookes, C. Methanol oxidation on $\mathrm{Fe}_{2} \mathrm{O}_{3}$ catalysts and the effects of surface Mo. Faraday Discuss. 2016, 188, 387-398. [CrossRef]

132. Bowker, M.; Brookes, C.; Carley, A.F.; House, M.P.; Kosif, M.; Sankar, G.; Wawata, I.; Wells, P.P.; Yasenevaz, P. Evolution of active catalysts for the selective oxidative dehydrogenation of methanol on $\mathrm{Fe}_{2} \mathrm{O}_{3}$ surface doped with Mo oxide. Phys. Chem. Chem. Phys. 2013, 15, 11988-12003. [CrossRef]

133. Dias, A.P.S.; Montemor, F.; Portela, M.F.; Kiennemann, A. The role of the suprastoichiometric molybdenum during methanol to formaldehyde oxidation over Mo-Fe mixed oxides. J. Mol. Catal. A Chem. 2015, 397, 93-98. [CrossRef]

134. Pham, T.T.P.; Nguyen, P.H.D.; Vo, T.T.; Nguyen, H.H.P.; Luu, C.L. Facile method for synthesis of nanosized $\beta-\mathrm{MoO}_{3}$ and their catalytic behavior for selective oxidation of methanol to formaldehyde. Adv. Nat. Sci. Nanosci. Nanotechnol. 2015, 6, 045010. [CrossRef]

135. Machiels, C.J.; Cheng, W.H.; Chowdhry, U.; Farneth, W.E.; Hong, F.; Mc Carron, E.M.; Sleight, A.W. The effect of the structure of molybdenum oxides on the selective oxidation of methanol. Appl. Catal. 1986, 25, 249-256. [CrossRef]

136. Tatibouet, J.M.; Germain, J.E.; Volta, J.C. Structure-sensitive catalytic oxidation: Alcohols on graphite-supported molybdenum trioxide. J. Catal. 1983, 82, 240-244. [CrossRef]

137. Castillo, R.; Dewaele, K.; Ruiz, R. Mechanical mixtures of alpha-Sb204 and $\mathrm{MoO}_{3}$ as highly selective catalysts for the oxidation of methanol to formaldehyde. Appl. Catal. A Gen. 1996, 153, 1-8. [CrossRef]

138. Briand, L.E.; Farneth, W.E.; Wachs, I.E. Quantitative determination of the number of active surface sites and the turnover frequencies for methanol oxidation over metal oxide catalysts. I. Fundamentals of the methanol chemisorption technique and application to monolayer supported molybdenum oxide catalysts. Catal. Today 2000, 62, 219-229. [CrossRef]

139. Chen, Y.; Wachs, I.E. Tantalum oxide-supported metal oxide $\left(\mathrm{Re}_{2} \mathrm{O}_{7}, \mathrm{CrO}_{3}, \mathrm{MoO}_{3}, \mathrm{WO}_{3}, \mathrm{~V}_{2} \mathrm{O}_{5}\right.$, and $\left.\mathrm{Nb}_{2} \mathrm{O}_{5}\right)$ catalysts: Synthesis, Raman characterization and chemically probed by methanol oxidation. J. Catal. 2003, 217, 468-477. [CrossRef]

140. Cairati, L.; Carbucicchio, M.; Ruggeri, O.; Trifiro, F. Study of the interaction of $\mathrm{Fe}_{2} \mathrm{O}_{3}-\mathrm{MoO}_{3}$ with several supports. Stud. Surf. Sci. Catal. 1979, 3, 279-292. [CrossRef]

141. Forzatti, P. On the deactivation of $\mathrm{Fe}_{2} \mathrm{O}_{3}-\mathrm{MoO}_{3} / \mathrm{SiO}_{2}$ catalysts in the oxidation of methanol to formaldehyde. React. Kinet. Catal. Lett. 1982, 20, 213-218. [CrossRef]

142. Carbucicchio, M.; Forzaiti, P.; Tronconi, E.; Villa, P.L.; Trifiro', F. Deactivation of silica supported $\mathrm{Fe}_{2} \mathrm{O}_{3}-\mathrm{MoO}_{3}$ catalyst for the oxidation of methanol. Stud. Surf. Sci. Catal. 1980, 6, 103-113. [CrossRef]

143. Hill, C.G.; Wilson, J.H. Raman spectroscopy of iron molybdate catalyst systems. Part II. Preparation of supported catalysts. J. Mol. Catal. 1991, 67, 57-77. [CrossRef]

144. Rozanov, V.V.; Vieira Soares, A.P.; Portela, M.F. Methanol to formal-dehyde oxidation over silica supported Iron-molybdates: Effect of iron precursor. In Proceedings of the Book of Extended Abstracts, 4th ed.; World Congress on Oxidation Catalysis: Berlim/Potsdam, Germany, 2001.

145. Peyrovi, M.H.; Parsafard, N.; Hasanpour, H. Catalytic Study of the Partial Oxidation Reaction of Methanol to Formaldehyde in the Vapor Phase. Bull. Chem. React. Eng. Catal. 2018, 13, 520-528. [CrossRef]

146. Nieto, J.; Lopez, F.T. The Role of Promoters in Selective Oxidation with Mixed Oxides Based Catalysts. In Proceedings of the Advances in Catalyst Design, Trieste, Italy, 10-14 November 1992; Volume 2, p. 412.

147. Klissurski, D.; Rives, V.; Pesheva, Y.; Mitov, I.; Abadzhjieva, N. Iron-chromium-molybdenum oxide catalysts for methanol oxidation. Catal. Lett. 1993, 18, 265-271. [CrossRef]

148. Estevez Sanchez, A.M.; Fernandez Tena, A.; Marquez Moreno, M.C. Oxidation of Methanol to Formaldehyde on IronMolybdenum Oxide Catalysts, with and without Chromium as a promoter. Kinet. Catal. Lett 1989, 38, 193-198. [CrossRef]

149. Estevez, A.; Marquez, M.; Tena, A.; Del Arco, M.; Martin, C.; Rives, V. Catalytic and selectivity at low temperature of ironmolybdenum oxide catalysts in methanol oxidation to formaldehyde. Chem. Biochem. Eng. Q. 1990, 4, 61-65.

150. Pesheva, Y.; Mitov, I.; Klissurski, D. Study on the Stability of Molybdate Based Catalysts. In Proceedings of the Book of Abstracts Europacat II Congress; The Maastricht Exhibition \& Conference Centre (MECC), Maastricht, The Netherland, 3-8 September 1995.

151. Ivanov, K.; Mitov, I.; Krustev, S. Selective oxidation of methanol on Fe-Mo-W catalysts. J. Alloys Compd. 2000, 309, 57-60. [CrossRef]

152. Pernicone, N. Advances and Trends in the Catalysis of Formaldehyde Production Over Fe-Mo Catalysts. In Proceedings of the Meeting on Industrial and Environmental Catalysis, Lisbon, Spain, 12 May 1995; pp. 15-19.

153. Ding, H.; Lin, H.; Sadigh, B.; Zhou, F.; Ozoliňš, V.; Asta, M. Computational investigation of electron small polarons in $\alpha-M_{3} \mathrm{O}_{3}$. J. Phys. Chem. C 2014, 118, 15565-15572. [CrossRef]

154. Choksi, T.; Greeley, J. Partial oxidation of methanol on $\mathrm{MoO}_{3}$ (010): A DFT and microkinetic study. ACS Catal. 2016, 6, 7260-7277. [CrossRef]

155. Ivanov, K.I.; Dimitrov, D.Y. Deactivation of an industrial iron-molybdate catalyst for methanol oxidation. Catal. Today 2010, 154, 250-255. [CrossRef]

156. Matthey, J. A Formaldehyde Magazine from Johnson Matthey—Safe Operations, the FORMOX Process. Informal Speaking. Available online: https: / / matthey.com/en (accessed on 22 July 2017). 
157. Mitov, I.; Asenov, S.; Tomov, T.; Klissurski, D. In situ mössbauer study of the interaction of methanol with an iron-molybdenum oxide catalyst. J. Phys. Chem. C 2007, 111, 5389-5393. [CrossRef]

158. Jacques, S.D.M.; Leynaud, O.; Strusevich, D.; Beale, A.M.; Sankar, G.; Martin, C.M.; Barnes, P. Redox behavior of Fe-Mo-O catalysts studied by ultrarapid in situ diffraction. Angew. Chemie Int. Ed. 2006, 45, 445-448. [CrossRef]

159. Jacques, S.D.M.; Leynaud, O.; Strusevich, D.; Stukas, P.; Barnes, P.; Sankar, G.; Sheehy, M.; O’Brien, M.G.; Iglesias-Juez, A.; Beale, A.M. Recent progress in the use of in situ X-ray methods for the study of heterogeneous catalysts in packed-bed capillary reactors. Catal. Today 2009, 145, 204-212. [CrossRef]

160. Abaulina, L.I.; Kustova, G.N.; Klevtsova, R.F.; Popov, B.I.; Bibin, V.N.; Melekhina, V.A.; Kolomiichuk, V.N.; Boreskov, G.K. Study of an iron-molybdenum oxide catalyst for the oxidation of methanol to formaldehyde. $\mathrm{V}$. The formation of a solid solution of molybdenum trioxide in Iron molybdate and the nature of the catalytically active component. Kinet. Catal. Engl. Transl. 1976, 17, 1126-1132.

161. Burriesci, N.; Garbassi, F.; Petrera, M.; Petrini, G.; Pernicone, N. Solid state reactions in Fe-Mo oxide catalysts for methanol oxidation during aging in industrial plants. Stud. Surf. Sci. Catal. 1980, 6, 115-126. [CrossRef]

162. Arruano, J.; Wanke, S. Effect of High Temperature Treatment on the Properties of Fe/Mo Oxide Catalysts. Canad. J. Chem. Eng 1975, 53. [CrossRef]

163. Aruanno, J.; Wanke, S. Rates of nethanol oxidation over thermally treated Fe-Mo oxide catalysts. Can. J. Chem. Eng. 1977, 55, 93-95. [CrossRef] 